\title{
Seismic response of a masonry church in Central Italy: the role of interventions on the roof
}

\author{
Gessica Sferrazza Papa ${ }^{1}$ (D) Vito Tateo ${ }^{2}$ (D) $\cdot$ Maria Adelaide Parisi ${ }^{2}$ (D) $\cdot$ Siro Casolo $^{2}$ (D)
}

Received: 28 February 2020 / Accepted: 23 October 2020 / Published online: 10 November 2020

(c) The Author(s) 2020

\begin{abstract}
The seismic response of a medieval church in Central Italy is analyzed considering the two roof configurations, i.e., reinforced concrete and timber roofs, that the church had in different periods of its existence. Structural interventions and changes are common in the churches of this territory, where frequent earthquakes put these buildings at risk. The church studied here, St. Salvatore in Acquapagana (Serravalle di Chienti, province of Macerata), was damaged by the 1997 Umbria-Marche and the 2016 Central Italy earthquakes. Between these two seismic events, the church was repaired, and the concrete roof was substituted with a lighter timber roof. To investigate the influence of this change on the seismic response, a study was performed at the building and façade macroelement scales using the finite element model and rigid body spring model, respectively. For each approach, the two roof configurations were considered, and two strong motion records, from September 26, 1997, and October 30, 2016, were applied. The results show that the concrete roof improves the box-like behavior, but it increases the vulnerability of the masonry structures, characterized by a limited tensile strength. Conversely, in the timber roof configuration, the most vulnerable areas of the structure are the intersections between structural elements.
\end{abstract}

Keywords Masonry churches $\cdot$ Central Italy earthquakes $\cdot$ Seismic damage $\cdot$ Roof interventions $\cdot$ Nonlinear dynamic analysis $\cdot$ RBSM

\section{Introduction}

Over the last 20 years, Central Italy has experienced several seismic events that have seriously affected the cultural heritage building stock, composed to a large extent of masonry churches. The seismic swarm of the 2016 Central Italy earthquake, with three major damaging shocks, arrived in a relatively short span of time, on August $24(6.0 \mathrm{Mw})$, on October $26(5.9 \mathrm{Mw})$, and on October $30(6.5 \mathrm{Mw})$, covering a large area of approximately $30000 \mathrm{~km}^{2}$, affecting approximately thirty different dioceses (Penna et al. 2019).

Gessica Sferrazza Papa

gessica.sferrazza@polimi.it

1 Department of Architecture and Urban Studies, Politecnico di Milano, Milan, Italy

2 Department of Architecture, Built Environment and Construction Engineering, Politecnico di Milano, Milan, Italy 
The high vulnerability of churches has been well known since the Friuli earthquake of 1976, when the first methodology for the damage and vulnerability assessment of churches was elaborated (Doglioni et al. 1994). The church structures may be considered composed of a series of structural elements (macroelements), which show recurring failure modes, ultimately evolving into a kinematic chain (mechanisms) when subjected to seismic action (Petrini et al. 1999). A set of 28 failure mechanisms have been identified as the most frequent in churches (DCPCM-DPC MIBAC 2006). This set is used as a reference for describing damage in postevent surveys or vulnerability in a preventive analysis (Lagomarsino and Podestà 2004a, b). The methodology has been employed in several damage survey campaigns after the major earthquakes of the last decade: L'Aquila (2009, Mw 6.3) (Binda et al. 2010; Da Porto et al. 2012; Lagomarsino 2012; Brandonisio et al. 2013), Pianura Padana (2012, Mw 5.9) (Indirli et al. 2012; Sorrentino et al. 2014; Valente et al. 2017; Valente and Milani 2018a), and Central Italy (2016, Mw 6.2) (Carbonari et al. 2017; Cescatti et al. 2017; Borri et al. 2018; Penna et al. 2019; Sorrentino et al. 2019). The method has been applied to earthquakes in other territories, e.g., in the Philippines (D'Ayala and Benzoni 2012) and in New Zealand (Marotta et al. 2017), and it is currently under study in Québec.

Two other important seismic events, the 1997 Umbria-Marche and 2002 Molise earthquakes, have particularly shown the effect of strengthening and repairing interventions executed in the years preceding the events (Tobriner et al. 1997; Lagomarsino 1998). As observed in (Modena and Binda 2009; Lagomarsino and Podestà 2004a; Binda and Saisi 2005), inappropriate modifications and structural interventions could increase the vulnerability of a building. Over the years, the practice of intervention for historical buildings has been regulated or influenced by National Building Codes and Charters of Restoration (ICOMOS 2019). Churches with extended interventions that abnormally increased their local mass and stiffness often reported severe damage. After the negative outcomes observed in the 1997 Umbria-Marche earthquake, a specific sensibility regarding the intervention practice developed. In 2000, the Regional Authority of Marche published recommendations in support of practitioners, with indications for proper reconstruction and repair interventions (Doglioni and Mazzotti 2007).

In this context, this work focuses on the church of San Salvatore in Acquapagana, Macerata. The church suffered damage after the 1997 Umbria-Marche and 2016 Central Italy earthquakes. Between these seismic events, interventions in the form of repairs were performed. Following the recommendations of those years, the concrete roof was replaced with a light timber roof. In this work, numerical models are developed to reproduce the postearthquake damage and to support the results of a previous qualitative study on the same church (Sferrazza Papa and Silva 2018). The aim is to investigate the influence of the two types of roofs on the structural seismic response. The church is studied by modeling the two configurations (concrete roof and light timber roof) and applying both earthquakes (the 1997 Umbria-Marche event and the 2016 Central Italy event) to each model.

Several approaches may be employed to assess the seismic vulnerability or the state of damage of churches. Among these, the most frequently adopted are empirical, calibrated with statistical analyses generally used for large-scale investigation (Lagomarsino and Podestà 2004a, b), and numerical, based on a numerical analysis of the structural behavior suitable for detailed studies of a specific asset (Valente et al. 2017; Valente and Milani 2018a). The availability of effective computational tools has facilitated the achievement of numerical results. Together with empirical considerations, these tools provide a comprehensive vision of the structural behavior of buildings subjected to earthquakes. In the numerical modeling of masonry structures, two approaches are generally taken: micromodeling and macromodeling. The former considers the composite nature of the masonry, 
while the latter defines an equivalent homogeneous material (Lourenço 2002). Due to the level of detail, the micromodeling approach requires a higher computational effort. For this reason, this approach is not suitable for an analysis performed on the entire building but may be useful for local analyses considering that churches tend to develop local mechanisms. For this reason, when needing to study the behavior of a building with a higher level of detail, single macroelements, such as the façade, are isolated and analyzed by defining specific boundary conditions.

Based on these considerations, this work applies two approaches. In the first phase, a finite element model (FEM) is elaborated with Abaqus (2016) to study the problem at the building scale; in the second phase, the façade macroelement is isolated to investigate the local behavior of the structure based on rigid elements connected with springs (rigid body spring model, RBSM) (Casolo 2000). The former considers the masonry as an isotropic and homogeneous material, while the latter, the orthotropic nature of the masonry and the different mechanical characteristics of the multileaf wall structure. In both cases, two configurations are modeled, and the effect of the roof interventions is evaluated by applying two recorded seismic events to each model. Finally, a comparison between the results from the two approaches is presented, and considerations on the influence of the interventions on the building are expressed.

\section{The church of San Salvatore}

The church of San Salvatore is in Acquapagana, a small town located in Central Italy, in the Province of Macerata. San Salvatore is an example of the medieval typology most widespread in the region. The church is part of a monastery, which collapsed in the UmbriaMarche earthquake of 1997 (Sorrentino et al. 2004) and was rebuilt. A lack of detailed information led to the decision to limit the analyses to the church building. According to (Borri et al. 2018), more than 450 churches of this style have been identified in Umbria by the Italian Conservation and Protection body (Soprintendenza Archeologia, Belle Arti e Paesaggio). The simplicity of the plan configuration of San Salvatore is typical of other churches in the area: single nave churches represent 68 out of the 107 damaged churches surveyed in De Matteis et al. (2017), almost 64\% of the total, and 350 over 500, i.e., $70 \%$, in Carbonari et al. (2017). Moreover, several churches of the sample were subjected to interventions after the 1997 Umbria-Marche earthquake.

San Salvatore was built at the beginning of the $11^{\text {th }}$ century. The church has a single and symmetric nave, with the entrance in axis with the square apse; a bell tower intersects the structure of the church at the northeast side (Fig. 1a). The only structural elements that give a rhythm to the straight and long space of the nave are the arches. In the longitudinal walls of the nave, small openings interrupt the continuity of the walls (Fig. 1c, d), while a rose window characterizes the façade (Fig. 1b). The façade reflects the simplicity of the church. It has a hut shape and a simple white stone portal. The thickness of the walls is constant for both the façade and the lateral walls, with an average of approximately $85 \mathrm{~cm}$. The walls are composed of three leaves with some cross-stone blocks. The external leaves are made of dressed stones, joined by thin layers of mortar, set up in a regular pattern (Sferrazza Papa and Silva 2018).

The roof has been changed over time, keeping its configuration unaltered. Before the 1997 Umbria-Marche earthquake, the original timber roof had been replaced with a concrete roof, according to strengthening criteria of the time. The church was severely 


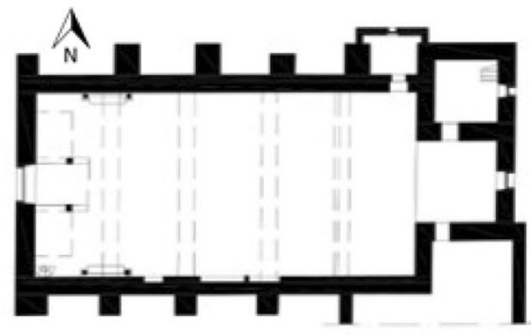

(a)

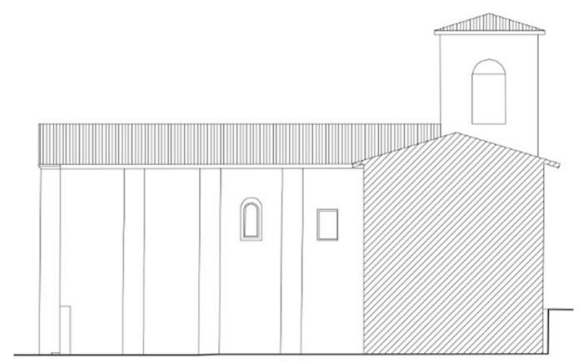

(c)

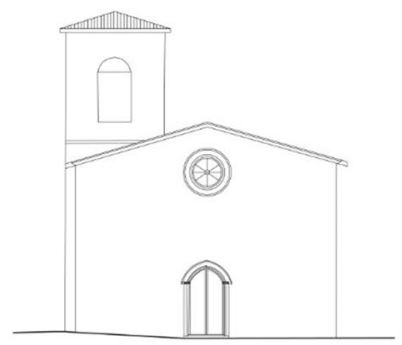

(b)

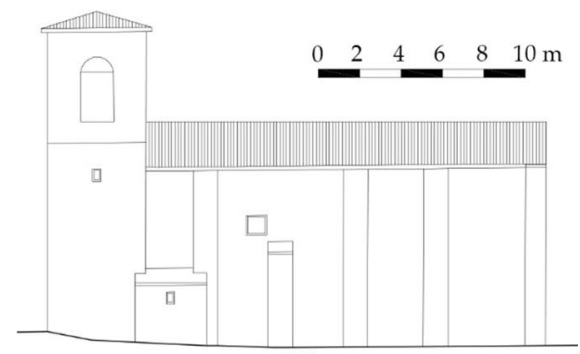

(d)

Fig. 1 Plan and elevation of the San Salvatore church: a plan at the entrance level; b principal façade; c south elevation; $\mathbf{d}$ north elevation

damaged in 1997, and some repairs and rebuilding works were performed. A new light timber roof was realized, and some tie rods were added in correspondence with the impost of the arches. Observing the plan configuration, some of the buttresses that confine the lateral walls of the nave are not aligned with the arches of the nave. For this reason, the assumption that they were constructed in a second moment was formulated. Other hypotheses on the realization of the buttresses and on the seismic history for this church were expressed in (Sorrentino et al. 2004). A similar church in an area nearby, San Salvatore di Campi, was subjected to this intervention after the 1703 earthquake (Borri et al. 2018).

\subsection{The seismic context}

The area has moderate seismicity (OPCM 2006) and a long seismic history (INGV 2015). In recent decades, two strong seismic events, the 1997 Umbria-Marche and the 2016 Central Italy earthquakes, occurred. Both events were characterized by seismic sequences.

Earthquakes in the Apennine area are generated by strike-slip faults with SSE-NNW orientations (Gruppo di Lavoro INGV sul terremoto in centro Italia 2016). For this study, the recorded data from the Colfiorito (CLF) station were used (Luzi et al. 2019), with no recorded and soil data available for the church site. For this reason, the accelerations recorded at the Colfiorito station were directly applied at the base of the church for the following analysis. Table 1 reports the data of the CLF station. Figure 2 shows the relative positions of the CLF station, the church, and the epicenters of the two earthquakes.

Table 2 provides additional information on the main seismic shocks and the distances between the epicenters, the church and the CLF station. The comparison of the data motivates 
Table 1 Data from the Colfiorito (CLF) recording station (Luzi et al. 2019)

\begin{tabular}{lllllll}
\hline Station Code & Latitude & Longitude & Altitude & Site class & Morphology & Topography \\
\hline CLF & 43.03671 & 12.92043 & $701 \mathrm{~m}$ & D* & Valley center & T1** \\
\hline
\end{tabular}

*Refers to the soil classification expressed in Eurocode 8 (CEN 2005)

***Refers to topographical categories presented in Table 3.2.III of NTC 2018 (NTC 2018)

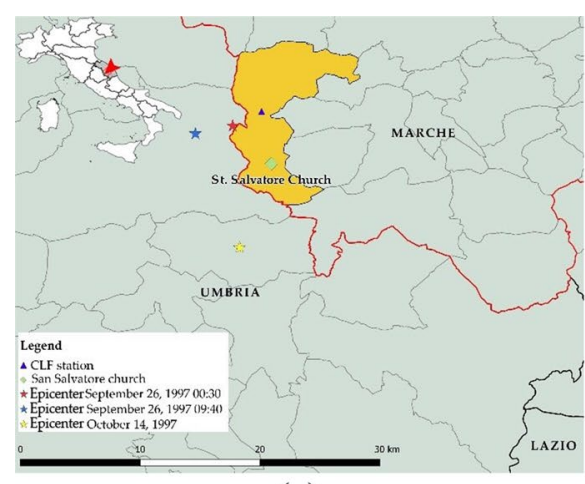

(a)

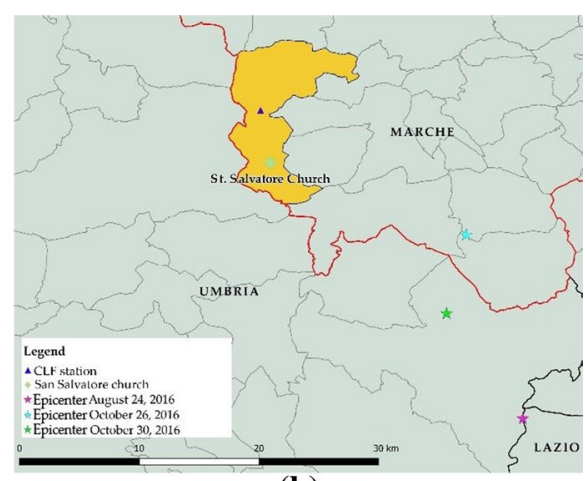

(b)

Fig. 2 Localization map showing the church $(42.983453,12.930303)$ in Acquapagana within the municipality of Serravalle di Chienti (yellow area), the recording station (43.03671, 12.92043), and the epicenters of the major shocks of the two considered earthquakes: a the 1997 Umbria-Marche earthquake; b the 2016 Central Italy earthquake

us to choose, for each event, the episode with the worst conditions. The two selected episodes (September 26, 1997, at 09:40 a.m. and October 30, 2016) are framed in red in the table.

Figure 3 was elaborated by overlaying different information: the PGA isocurves, the position of the CLF station, the church, and the epicenters. Both the recording station and the church are between the $12 \% \mathrm{~g}$ and $18 \% \mathrm{~g}$ isocurves. For this reason, assuming these accelerations at the base of the church was considered acceptable.

Table 2 Data on the principal shocks of the two studied earthquakes. This table includes the distances from the recording station and the church to the epicenters and the depth and the magnitude for each seismic event. Time is specified as UTC

\begin{tabular}{|c|c|c|c|c|c|c||c|}
\hline \multirow{2}{*}{ Seismic events } & \multicolumn{3}{|c|}{ The 1997 Umbria-Marche earthquake } & \multicolumn{3}{c|}{ The 2016 Central Italy earthquake } \\
\cline { 2 - 7 } & $\begin{array}{c}\mathbf{2 6} \text { Sept. } \\
\mathbf{0 0 : 3 3}\end{array}$ & $\begin{array}{c}\mathbf{2 6} \text { Sept. } \\
\mathbf{0 9 : 4 0}\end{array}$ & $\begin{array}{c}\mathbf{1 4} \text { Oct. } \\
\mathbf{1 5 : 2 3}\end{array}$ & $\begin{array}{c}\mathbf{2 4} \text { Aug. } \\
\mathbf{1 : 3 6}\end{array}$ & $\begin{array}{c}\mathbf{2 6} \text { Oct. } \\
\mathbf{1 9 : 1 8}\end{array}$ & $\begin{array}{c}\mathbf{3 0} \text { Oct. } \\
\mathbf{0 6}: \mathbf{4 0}\end{array}$ \\
\hline $\begin{array}{c}\text { Distance from } \\
\text { epicenter to the } \\
\text { church (km) }\end{array}$ & 6.10 & 8.73 & 10.19 & 40.95 & 26.24 & 23.72 \\
\hline $\begin{array}{c}\text { Distance from the } \\
\text { station (km) }\end{array}$ & 3.84 & 7.96 & 15.60 & 45.49 & 27.16 & 31.04 \\
\hline Depth (km) & 5.70 & 5.70 & 6.00 & 8.1 & 7.5 & 9.20 \\
\hline Magnitude (Mw) & 5.70 & 6.01 & 5.65 & 6.0 & 5.90 & 6.5 \\
\hline $\begin{array}{c}\text { Distance from the } \\
\text { CLF station to the } \\
\text { church (km) }\end{array}$ & \multicolumn{7}{|c|}{6.00} \\
\hline
\end{tabular}




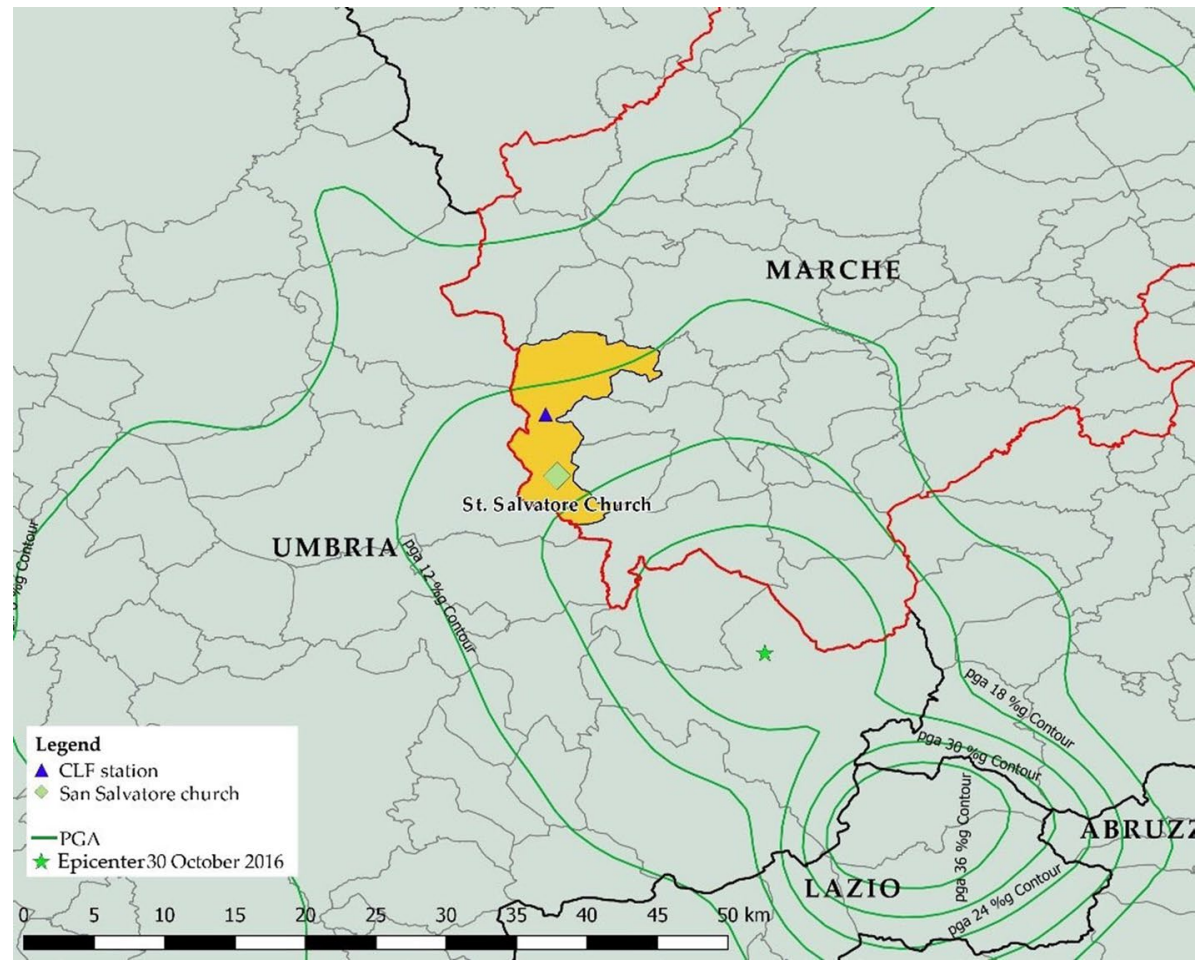

Fig. 3 This map shows the PGA isocurves for October 30, 2016 (12\% g), with the positions of the church and CLF station indicated. Source of the PGA isocurves: (Shake Maps INGV 2019)

\subsection{Description of the damage}

The church was severely damaged by the 1997 Umbria-Marche earthquake, as shown in Fig. 4. A portion of the gable and the upper-right corner of the façade collapsed, exposing the concrete roof that had probably produced a pounding effect on the wall. Shear cracks were visible in the façade between the rose window and the portal (Fig. 4a). Parts of the walls showed the detachment of the external leaf of the masonry (Fig. 4c). Additionally, the buttresses were damaged, losing the upper portion (Fig. 4d). In the background of Fig. 4a (red oval), some undamaged buttresses exhibit a different masonry pattern, especially at the borders, indicating that they may have been repaired and rebuilt at some time, and the damage seems to follow the discontinuity. The bell tower was also severely damaged: parts of the belfry collapsed, and shear cracks appeared along the height (Fig. 4b).

San Salvatore was damaged once more by the Central Italy earthquake in 2016. In this case, the damage information was collected by consulting a survey form completed during the postevent damage recognition campaign (DCPCM-DPC MIBAC 2006) and during 


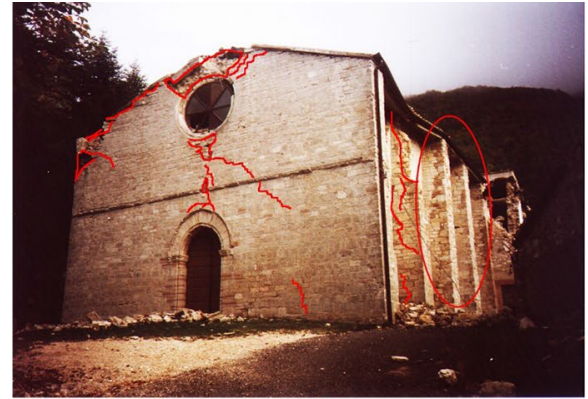

(a)

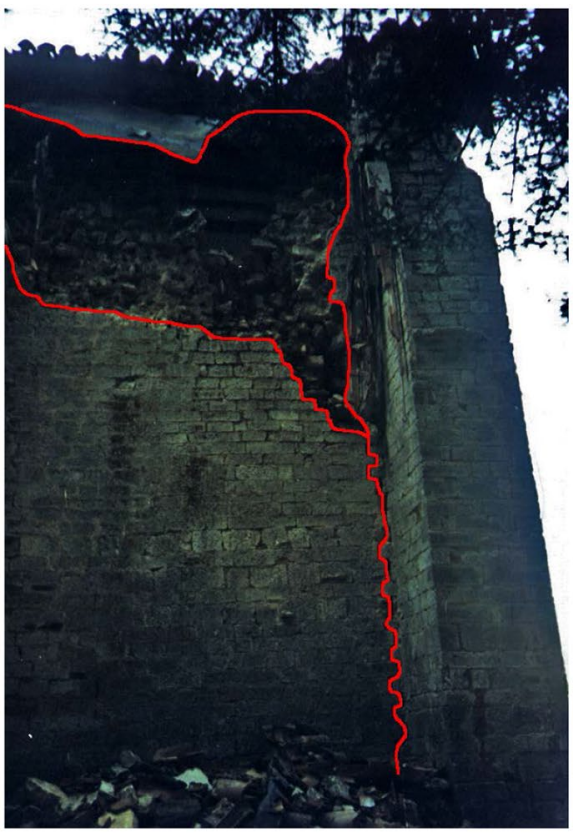

(c)

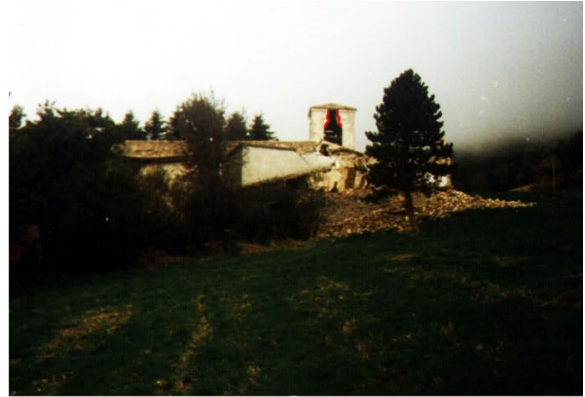

(b)

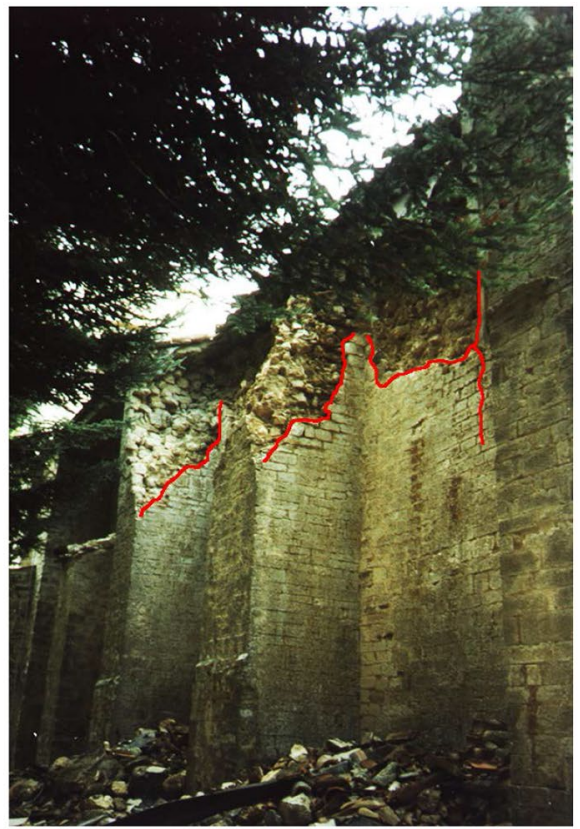

(d)

Fig. 4 The 1997 Umbria-Marche earthquake damage: a shear crack in the plane of the façade and some collapsed portions of the upper part of the façade and the gable; $\mathbf{b}$ collapse of the upper part of the belfry; $\mathbf{c}$ collapse of the external leaf of the lateral wall of the nave; $\mathbf{d}$ collapse of the upper portion of the buttresses (Sferrazza Papa and Silva 2018)

an on-site visit and survey performed in Spring 2017 (Fig. 5). The damage was less severe than that of the 1997 event and was mainly concentrated in the bell tower, the façade and the triumphal arch of the apse. Contrary to what happened in 1997, this time, no leaf separation was observed. Shear cracks were found in the bell tower (Fig. 5a, b) and in the façade (Fig. 5d). Moreover, a potential pounding effect of the timber beams of the roof was 


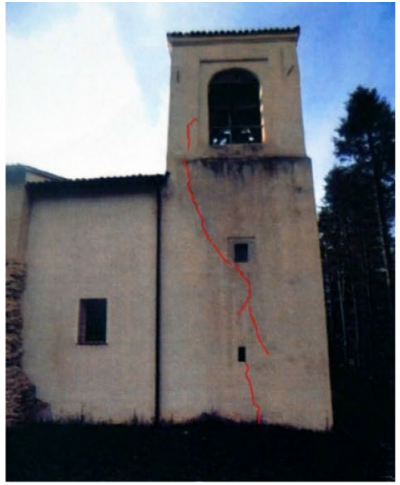

(a)

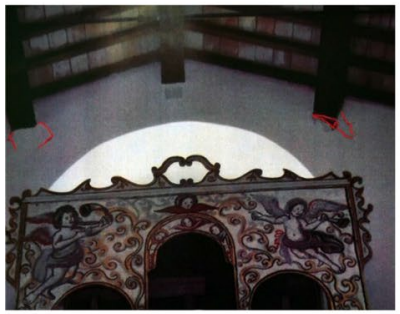

(c)

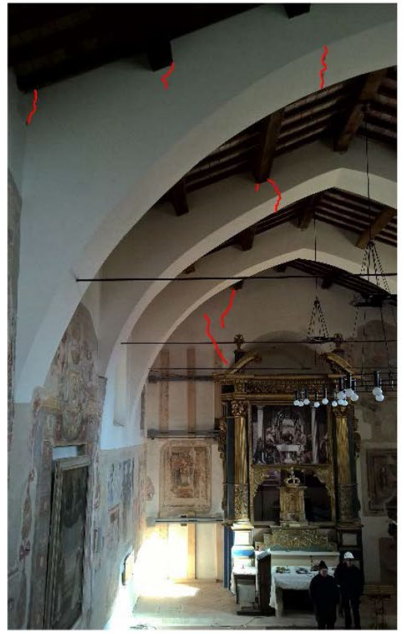

(e)

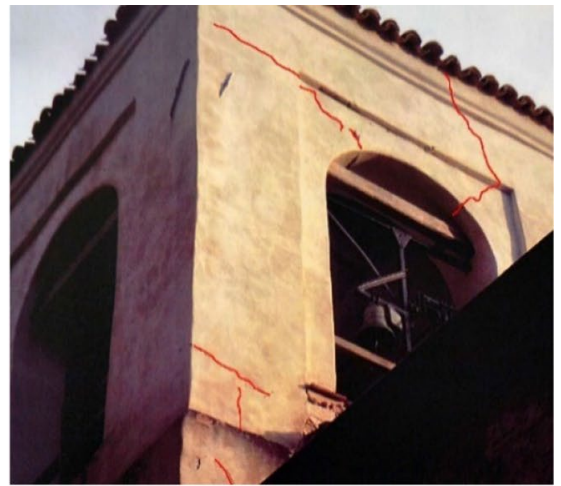

(b)

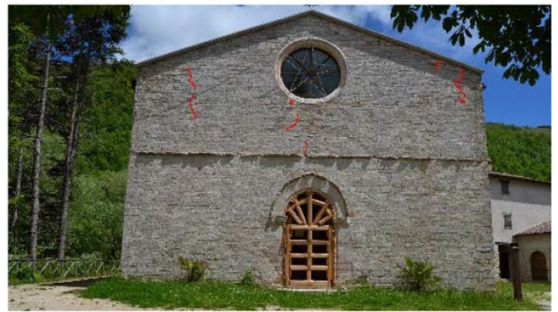

(d)

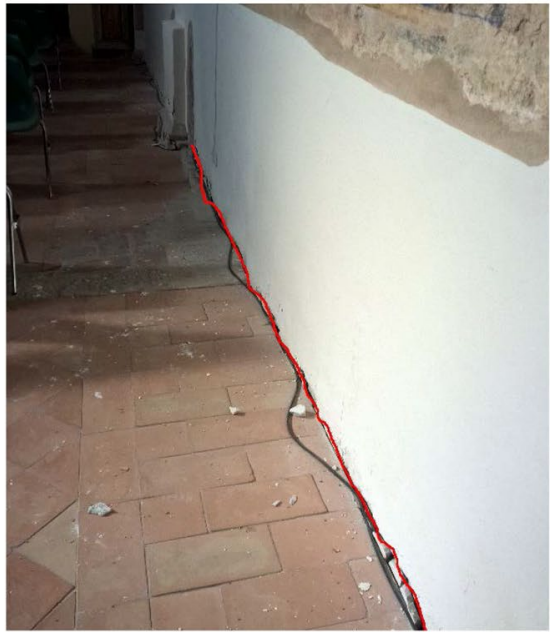

(f)

Fig. 5 The 2016 Central Italy earthquake damage: a shear cracks on the bell tower along the height; b shear cracks that trace the same path of the damage reported after the 1997 earthquake (Sferrazza Papa and Silva 2018); c pounding effect of the beam in the façade wall (Sferrazza Papa and Silva 2018); d crack in the upper-right corner in correspondence with the transversal walls of the nave and light damage in the plane of the façade (Sferrazza Papa and Silva 2018); e cracks in the arches in correspondence with the timber beams of the roof and in the triumphal arch close to the bell tower; $\mathbf{f}$ crack at the base of the south wall of the nave 
visible in the façade (Fig. 5c, d) and in the arches of the nave (Fig. 5e). Finally, a crack at the base of the south wall of the nave was observed (Fig. 5f).

\section{Selected ground motions}

In 1997 and 2016, the church endured a series of seismic shocks. For this study, the two most critical ones were chosen: those of September 26, 1997 (09:40 a.m.) and of October 30, 2016 (06:40 a.m.). Table 2 and Fig. 6 show the processed accelerograms recorded at the Colfiorito station for three components (NS, EW, and Z).

September 26, 1997 (09:40 a.m.)
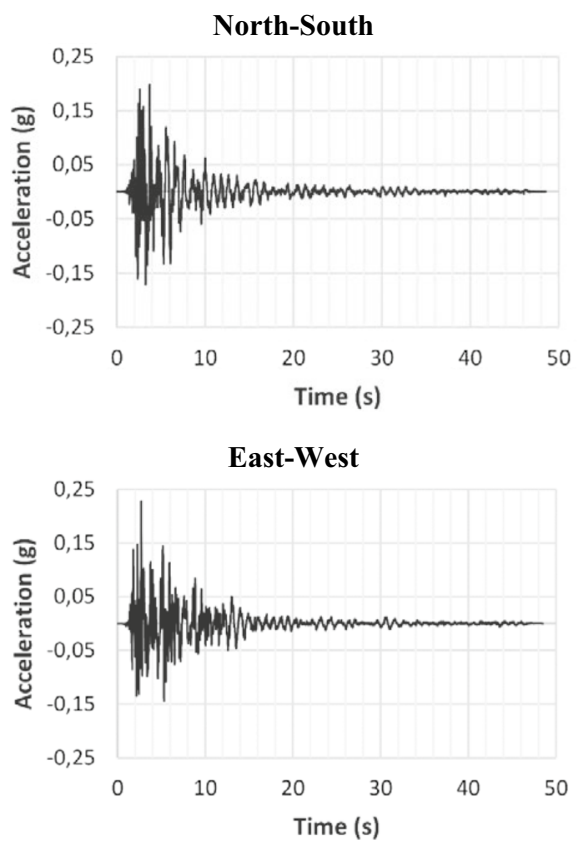

Z

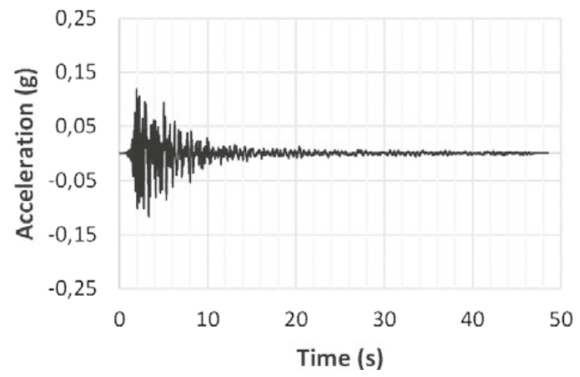

October 30, 2016 (06:40 a.m.)
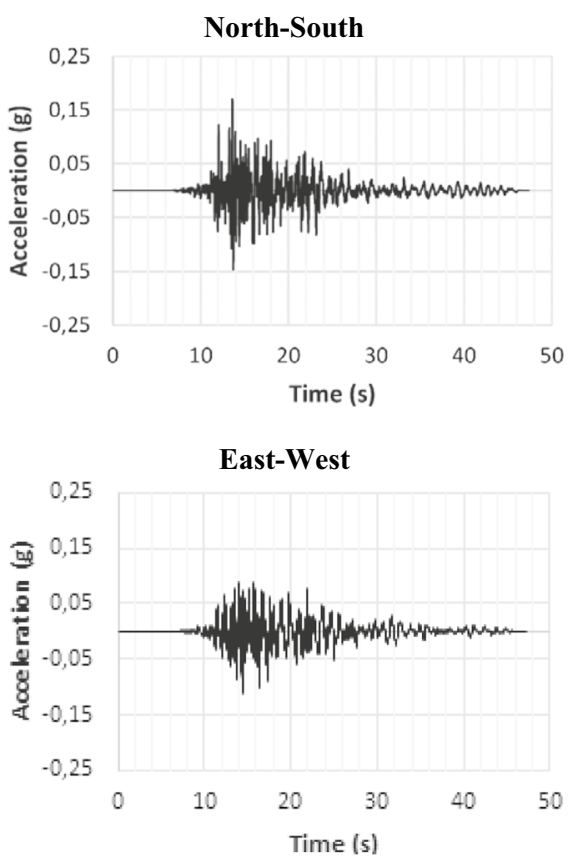

$\mathbf{Z}$

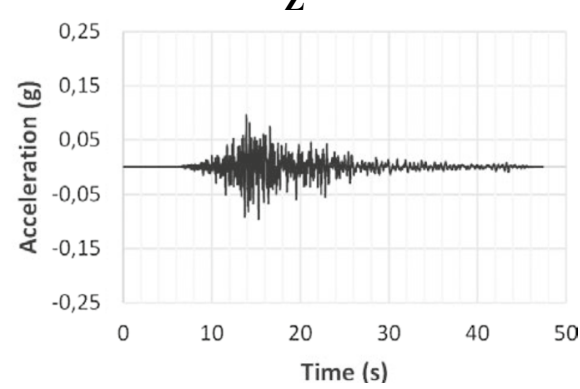

Fig. 6 Processed accelerograms recorded at the Colfiorito station during the two considered events. The data refer to the earthquake that occurred on September 26, 1997 (09:40 a.m.) and on October 30, 2016 (06:40 a.m.) for the three components (Luzi et al. 2019) 

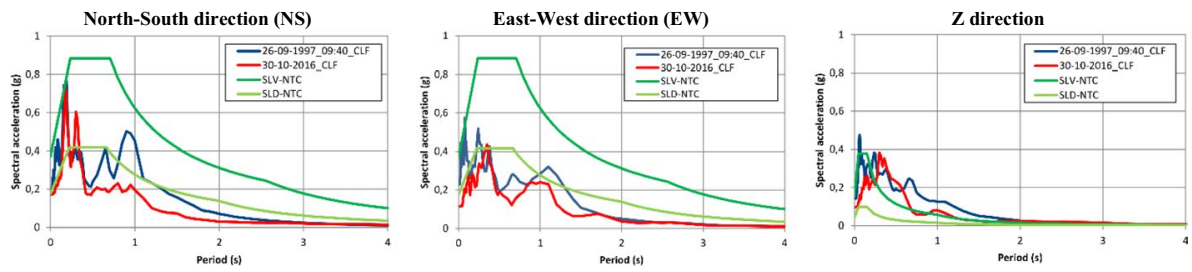

Fig. 7 Comparison of the elastic response spectra, in terms of the acceleration, of the two events with the SLD and SLV spectra from the National Building Code (NTC 2018)

To characterize the seismic events considered in the analyses, their elastic response spectra, in terms of the acceleration, were compared with those obtained with the standard procedure of the National Building Code (NTC 2018) at the site for the life-safety limit state (SLV), which corresponds to a return period of 475 years, and the damage limit state (SLD), which corresponds to 50 years, with reference to soil category D, the same as that of the Colfiorito station (Fig. 7).

Table 3 reports the peak ground acceleration $\left(\mathrm{PGA}_{\mathrm{x}}\right)$ and the spectral intensity $\left(\mathrm{SI}_{\mathrm{x}}\right)$, defined by Housner (Housner 1970), for the three directions. The Housner intensity is a parameter of seismic motion severity that is related to the potential damage expected from the considered earthquake because it is defined as the integral of the pseudovelocity response spectrum over the period range of [0.1-2.5 s]; the fundamental period of the majority of structures is in this range. In the table, T90 is the effective duration of the ground motion extracted from the ITACA database (Luzi et al. 2019), defined as the time required to pass from 5\% and 95\% of the Arias intensity (Arias 1970).

Figures 6 and 7 and Table 3 show the peculiarities of the two seismic events, pointing out some interesting aspects. The 1997 earthquake has comparable accelerations in the two horizontal directions (NS, EW) and high values in the vertical direction (Z). By contrast, the 2016 seismic event is characterized by higher values of acceleration in the north-south direction but always lower than those of the 1997 event. The duration of the seismic shock, defined as T90, is also a representative value: in the case of the 2016 seismic event, it had a higher value than in 1997. Figure 7 shows that both events are under the SLV code spectrum, with the only exception being the $\mathrm{Z}$ components. In particular, for period values lower than $0.1 \mathrm{~s}$ and higher than $1 \mathrm{~s}$, the 1997 event shows a higher spectral acceleration than that of the 2016 event; otherwise, they are comparable. Considering the Housner intensity, higher damage is expected when considering the 1997 earthquake.

Table 3 Seismic data of the September 26, 1997, and October 30, 2016, earthquakes

\begin{tabular}{lcc}
\hline Seismic event & $\begin{array}{l}\text { September 26, 1997 } \\
09: 40\end{array}$ & October 30, 2016 \\
\hline $\mathrm{PGA}_{\mathrm{NS}}\left(\mathrm{m} / \mathrm{s}^{2}\right)$ & 1.938 & 1.676 \\
$\mathrm{PGA}_{\mathrm{EW}}\left(\mathrm{m} / \mathrm{s}^{2}\right)$ & 2.234 & 1.107 \\
$\mathrm{PGA}_{\mathrm{Z}}\left(\mathrm{m} / \mathrm{s}^{2}\right)$ & 1.172 & 0.949 \\
$\mathrm{SI}_{\mathrm{NS}}(\mathrm{cm})$ & 73.850 & 38.668 \\
$\mathrm{SI}_{\mathrm{EW}}(\mathrm{cm})$ & 58.694 & 42.107 \\
$\mathrm{SI}_{\mathrm{Z}}(\mathrm{cm})$ & 31.283 & 21.513 \\
$\mathrm{~T} 90(\mathrm{~s})$ & 11.445 & 18.695 \\
\hline
\end{tabular}




\section{Finite element model}

\subsection{Church configurations and material properties}

The entire church was modeled with the finite element software Abaqus (Abaqus 2016). The masonry mesh was composed of 66055 tetrahedral first-order elements, which offer a good balance between computational effort and results. Each wall was discretized with at least four elements in its thickness (Fig. 8).

For the 1997 roof configuration, only the concrete slab was modeled, with 1812 quadrilateral shell elements (Fig. 9a), assumed to be $5 \mathrm{~cm}$ thick. A full connection between the concrete roof and the masonry structure was assumed. This assumption is based on photographic documentation, knowledge of the construction procedures of the time, and observation of the damage that occurred. For this reason, the shell elements were connected to the walls and the arches with tie constraints that avoid the relative rotations and displacements. For the 2016 configuration (timber roof), no bracing above the longitudinal beams or structural rafters were present. Secondary elements to support the roof tiles were not modeled. The timber beams of the roof were modeled with beam elements, while the tie rods were modeled as linear springs, with a negligible compressive stiffness (Fig. 9b). Both of these linear elements were connected to the walls through a built-in connection. The tensile stiffness of the springs $(k)$ was defined as $k=E A / l=13000 \mathrm{kN} / \mathrm{m}$, where $E$ is Young's modulus, equal to $200,000 \mathrm{MPa}, A$ is the cross section of the tie rods, with a diameter of $30 \mathrm{~mm}$, and $l$ is the length of the tie rods, equal to $10.60 \mathrm{~m}$.

In the Italian territory, multileaf masonry walls are frequent in historical buildings. In the case of three-leaf masonry walls, such as the one of San Salvatore, the external leaves are built with clay bricks or stones, and the internal core is composed of filler material with poor mechanical properties. This inhomogeneity in the section compromises the monolithic behavior. For the global analyses, however, the heterogeneity of the masonry and its orthotropic behavior were neglected to limit the computational effort and consider the limitation of the concrete damage plasticity (CDP) material model used for simulating the postelastic behavior of masonry (Lubliner et al. 1989; Lee and Fenves 1998). For these reasons, the properties of an equivalent homogeneous isotropic material have been defined according to the strength and Young's modulus values reported in the Italian code (CMIT 2019). The CDP model was conceived for concrete, but later, its use was extended to masonry structures with good results (Acito et al. 2014; Casolo et al. 2017; Valente et al. 2017; Bertolesi et al. 2018b; Sarhosis et al. 2018; Valente and Milani 2018b, c). These materials have a similar brittle behavior, associated with two main failure mechanisms: cracking under tension and crushing under compression. Using the CDP model, the mechanical properties of the material can be defined through distinct uniaxial tensile and compressive constitutive laws. Moreover, the damage variables $d_{t}$ (tensile) and $d_{c}$ (compressive), functions of the plastic strain, reduce the undamaged elastic stiffness $\boldsymbol{D}_{0}^{e l}$ and the damaged elastic stiffness $\boldsymbol{D}^{e l}$, which are defined in eq. (1):

$$
\boldsymbol{D}^{e l}=(1-d) \boldsymbol{D}_{0}^{e l}
$$

where $1-d=\left(1-s_{t} d_{c}\right)\left(1-s_{c} d_{t}\right)$.

Here, $s_{t}$ and $s_{c}$ are functions of the stress state and include the stiffness recovery effects associated with stress reversals. When the load changes from tension to compression, the compressive stiffness is recovered upon crack closure. By contrast, once crushing microcracks have developed, the tensile stiffness cannot be recovered. Hence, $s_{t}$ is equal to 1 , 
Fig. 8 The tetrahedral mesh of the church used for the analyses performed with Abaqus
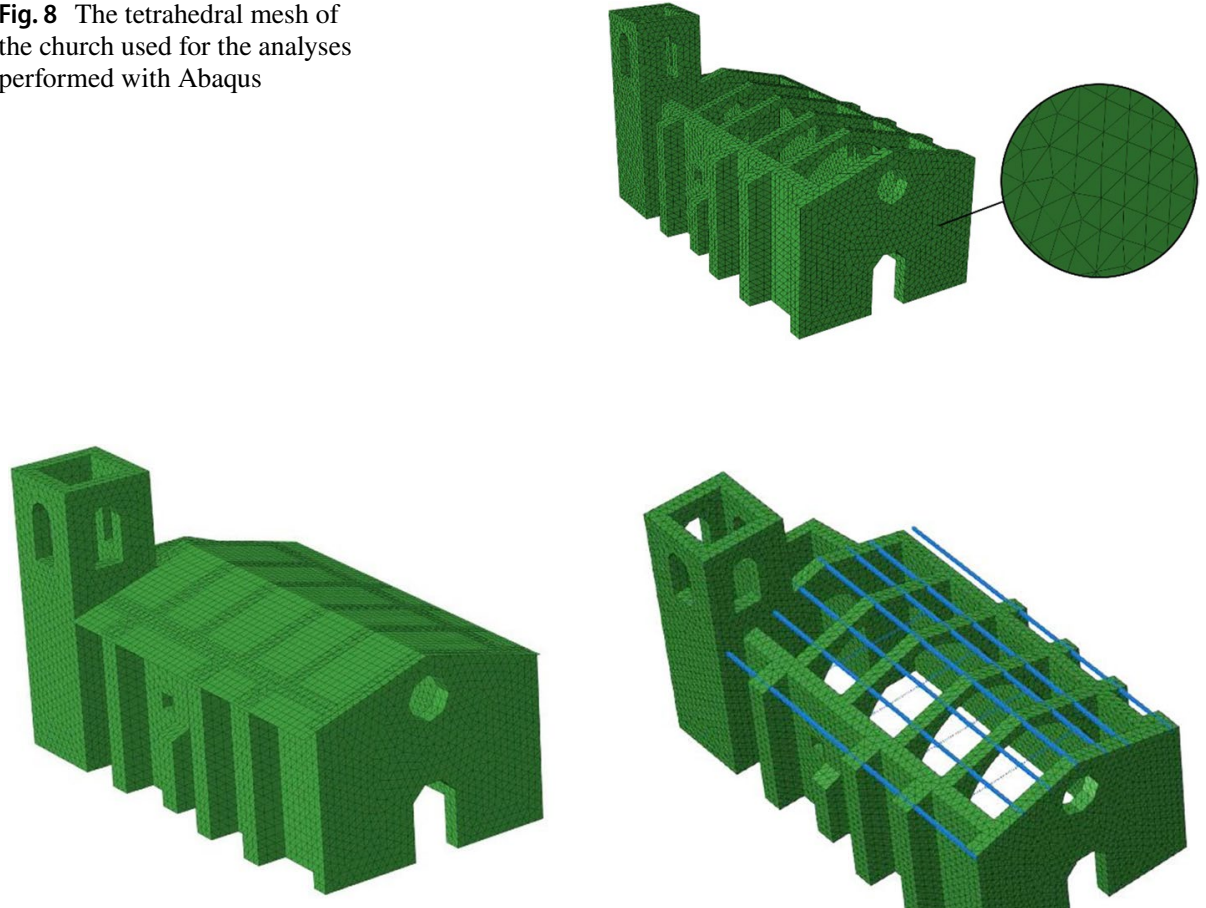

(a)

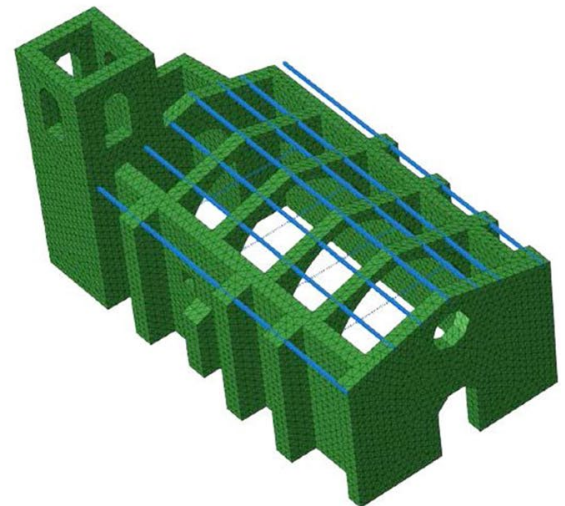

(b)

Fig. 9 The two structural configurations of the church: a the church with a concrete roof (1997 configuration); $\mathbf{b}$ the church covered with a light timber roof and with tie rods at the impost of the arches of the nave (2016 configuration)

and $s_{c}$ is 0 when all the eigenvalues of the effective stress tensor are negative; otherwise, it is equal to 1 when they are all positive. $d_{t}$ and $d_{c}$ are the two damage variables, which are functions, respectively, of the tensile and compressive plastic strains. For the analyses, the $d_{c}$ parameter was assumed to be equal to 0 , considering that the tensile strength of the material is significantly lower than the compressive strength and in agreement with the examples in the Abaqus manual and other works (e.g., Valente and Milani 2016). $d_{t}$ is zero for the elastic tensile strength and equal to 0.95 for the ultimate tensile strain.

The model parameters reported in Table 4 were assigned in accordance with the software documentation (Abaqus 2016) and other similar applications and experimental studies (e.g., Van Der Pluijm 1993).

The postelastic behavior in compression was defined through the definition of the compressive stress for different values of the inelastic strain $\tilde{\varepsilon}_{c}^{i n}$, in agreement with the values reported by other authors (Table 5), considering that the inelastic strain in the uniaxial case is (2): 
Table 4 Model parameters used for the analyses: the dilation angle $(\Phi)$, the correction parameter of the eccentricity $(e)$, the strength ratio $\left(\mathrm{f}_{\mathrm{b} 0} / \mathrm{f}_{\mathrm{c} 0}\right)$, the parameter $\left(\mathrm{K}_{\mathrm{C}}\right)$ of the shape of the yield surface in the deviatoric plane, and the viscosity parameter $(\mu)$

\begin{tabular}{lllll}
\hline$\Phi$ & $\mathrm{e}$ & $\mathrm{f}_{\mathrm{b} 0} / \mathrm{f}_{\mathrm{c} 0}$ & $\mathrm{~K}_{\mathrm{C}}$ & $\mu$ \\
\hline $10^{\circ}$ & 0.1 & 1.16 & $2 / 3$ & 0.002 \\
\hline
\end{tabular}

$$
\tilde{\varepsilon}_{c}^{i n}=\varepsilon_{c}-\frac{\sigma_{c}}{E_{0}}
$$

To avoid mesh-sensitive results (De Borst 1997; Abaqus 2016), the postelastic behavior in tension was defined in terms of the cracking displacements $u_{t}^{\text {ck }}$ (Table 5). The ultimate cracking displacement, at which the strength is almost zero, is obtained by considering a reasonable fracture energy $G_{f}$ equal to $48 \mathrm{~N} / \mathrm{m}$ (Bejarano-Urrego et al. 2018), which allows us to study the complete evolution of damage without convergence issues.

For the analyses, the walls and arches were associated with two different types of masonry: for the walls, uncut stone masonry, while for the arches, roughly cut stones with good masonry pattern. The relevant properties are reported in Table 5. For the first type of masonry, a correction coefficient equal to 0.8 was introduced, in agreement with the values reported in table C8A.2.2 (CMIT 2009) for masonry walls with a thick inner core and/or with poor mechanical properties.

The same CDP model was used for the concrete of the roof in the 1997 configuration. In the absence of information on the type of concrete, the properties of the material were taken from NTC (2018) for a C25/30. The inserted values correspond to an elastic modulus of 31,000 MPa, a compressive strength $\left(\sigma_{\mathrm{cu}}\right)$ of $14.2 \mathrm{MPa}$, and a tensile strength equal to 1.2 $\mathrm{MPa}$.

For the 2016 configuration with the timber roof, an elastic modulus parallel to the fiber equal to 10,000 MPa, corresponding to a softwood classified as S2 (UNI 11035 2010), was considered.

Table 5 Material properties for the masonry of the walls (uncut stone masonry) and of the arches (roughly cut stones with good masonry pattern) of the San Salvatore church (CMIT 2019)

\begin{tabular}{|c|c|c|c|}
\hline \multicolumn{2}{|c|}{ Walls $(\mathrm{E}=1152 \mathrm{MPa})$} & \multicolumn{2}{|c|}{ Arches $(\mathrm{E}=1740 \mathrm{MPa})$} \\
\hline \multicolumn{2}{|c|}{ Tensile behavior } & \multicolumn{2}{|c|}{ Tensile behavior } \\
\hline $\mathrm{u}_{\mathrm{t}}^{\mathrm{ck}}(\mathrm{mm})$ & $\sigma_{\mathrm{t}}(\mathrm{MPa})$ & $\mathrm{u}_{\mathrm{t}}^{\mathrm{ck}}(\mathrm{mm})$ & $\sigma_{\mathrm{t}}(\mathrm{MPa})$ \\
\hline 0.0 & 0.16 & 0.0 & 0.2 \\
\hline 0.6 & 0.0016 & 0.5 & 0.002 \\
\hline \multicolumn{2}{|c|}{ Compressive behavior } & \multicolumn{2}{|c|}{ Compressive behavior } \\
\hline$\tilde{\varepsilon}_{c}^{i n}$ & $\sigma_{\mathrm{c}}(\mathrm{MPa})$ & $\tilde{\varepsilon}_{c}^{i n}$ & $\sigma_{\mathrm{c}}(\mathrm{MPa})$ \\
\hline 0.000 & 1.55 & 0.000 & 3.10 \\
\hline 0.005 & 1.60 & 0.005 & 3.20 \\
\hline 0.015 & 0.00 & 0.015 & 0.00 \\
\hline
\end{tabular}




\subsection{Numerical results}

\subsubsection{Modal analyses}

A modal analysis was performed on both 3D models of the San Salvatore church for a preliminary assessment of the dynamic behavior. Figure 10 shows the most significant modal shapes of the 1997 configuration, the relevant natural periods, and the participating mass ratios for the longitudinal and transversal directions.

Mode 1 involves the upper part of the bell tower and the nave in the transversal direction with a participating mass ratio of almost $60 \%$. This is a high value for a masonry church, and it is due to the presence of the stiff concrete roof. Mode 2 has a displacement in the longitudinal direction, mainly concentrated on the bell tower with a participating mass ratio equal to almost 25\%. Modes 3 and 7 show a displacement in the diagonal direction of the upper part of the bell tower and a rotation that principally involves the nave. Mode 4 and Mode 5 cause the vertical deformation of the arches because of the compression and dilatation of the nave. Modes 6 and 8 are longitudinal modes that mainly involve the façade and the bell tower with light torsion.

Figure 11 shows the most significant modal shapes for the 2016 configuration (timber roof) with the corresponding period of vibration and participating mass ratio for the longitudinal and transversal directions. In this configuration, the first significant mode is the $9^{\text {th }}$ one, while the first modes locally activate only the roof. Mode 9 involves the nave, and it presents the highest participating mass ratio $(40.49 \%)$ in the transversal direction. Mode 11 follows the transversal direction, engaging the bell tower and the triumphal arch of the apse connected to it. Mode 12 presents the highest participating mass ratio in the longitudinal direction, with a value of almost $24 \%$, involving the bell tower and the nave. Mode 13 and Mode 25 are torsional modes that impact the nave. Mode 14 reaches almost 20\% of the participating mass ratio in the longitudinal direction, involving both the nave and the façade. Mode 17 shows a compression effect of the nave in the transversal direction, generating a vertical movement of the arches. Mode 22 principally shows a torsional mode of the bell tower.

Table 6 synthetizes the influence of the roof type on the vibration modes of the church structure. For the concrete roof configuration, Mode 1 (Fig. 10) is the main transversal mode, with a participating mass ratio of $60 \%$ and a period of $0.208 \mathrm{~s}$, while for the timber beam configuration, the highest participating mass ratio in the same direction appears in Mode 9 (Fig. 11), with a period of $0.257 \mathrm{~s}$. The concrete roof makes the structure stiffer in the transverse direction, reducing the vibration period by $20 \%$. The same considerations may be expressed for the longitudinal direction: the main modes are Mode 2 and Mode 6 (Fig. 10) for the concrete roof configuration and Mode 12 and Mode 14 (Fig. 11) for the timber roof case. The corresponding periods for each mode in the two configurations show stiffening due to the presence of the concrete roof, even if the percentage reduction is lower (14\% and $17 \%)$ than in the transverse direction (20\%). 


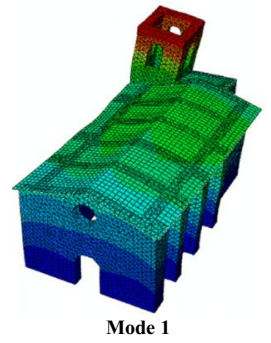

$\mathbf{T}=0.208 \mathrm{~s}$

PMR long. $=0.00 \%$

PMR trans. $=59.26 \%$

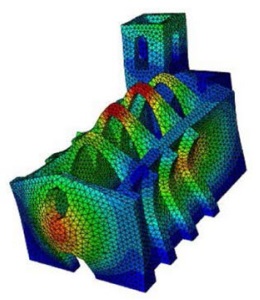

Mode 5

$$
\mathbf{T}=0.109 \mathrm{~s}
$$

PMR long. $=2.11 \%$

PMR trans. $=0.10 \%$

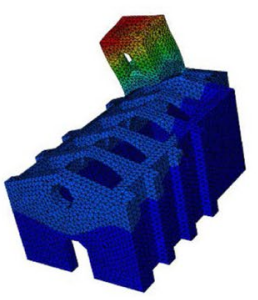

Mode 2

$\mathbf{T}=0.161 \mathrm{~s}$

PMR long. $=24.32 \%$

PMR trans. $=0.09 \%$

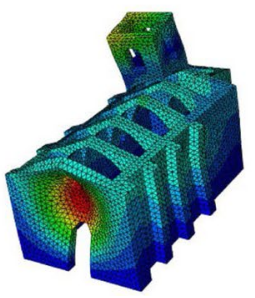

Mode 6

$$
\mathbf{T}=0.108 \mathrm{~s}
$$

PMR long. $=34.51 \%$

PMR trans. $=0.42 \%$

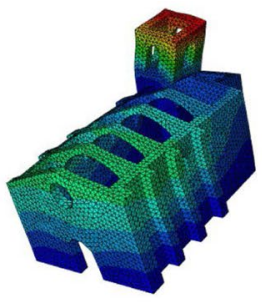

Mode 3

$\mathbf{T}=0.144 \mathrm{~s}$

PMR long. $=4.38 \%$

PMR trans. $=8.69 \%$

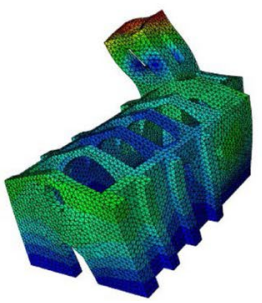

Mode 7

$\mathbf{T}=0.101 \mathrm{~s}$

PMR long. $=0.06 \%$

PMR trans. $=1.11 \%$

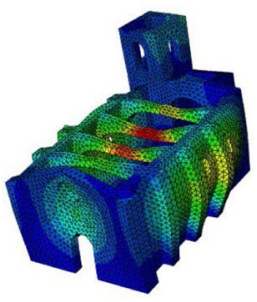

Mode 4

$\mathbf{T}=0.113 \mathrm{~s}$

PMR long. $=0.07 \%$

PMR trans. $=0.12 \%$

Fig. 10 Modal shapes of the 1997 roof configuration (concrete) with the relative values of several periods (T) and the participating mass ratios in the longitudinal (PMR long.) and transversal (PMR trans.) directions. Note: In the figure, the roof is shown only in Mode 1; in the other modes, the roof is not shown to make the behavior of the arches visible

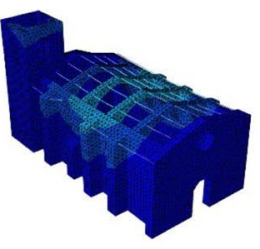

Mode 9 $\mathbf{T}=0.257 \mathrm{~s}$ PMR long. $=0.02 \%$ PMR trans. $=40.49 \%$

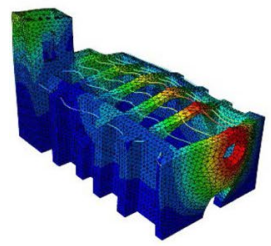

Mode 14

$$
\mathbf{T}=0.130 \mathrm{~s}
$$

PMR long. $=19.50 \%$

PMR trans. $=0.03 \%$

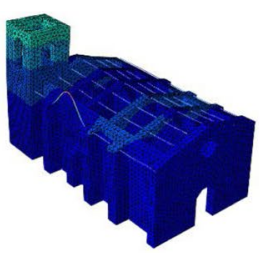

Mode 11 $\mathbf{T}=0.214 \mathrm{~s}$ PMR long. $=0.65 \%$ PMR trans. $=4.08 \%$

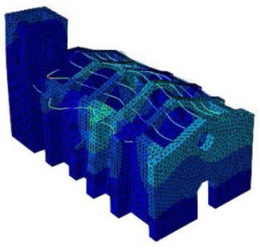

Mode 17

$$
\mathbf{T}=0.116 \mathrm{~s}
$$

PMR long. $=2.13 \%$

PMR trans. $=6.85 \%$

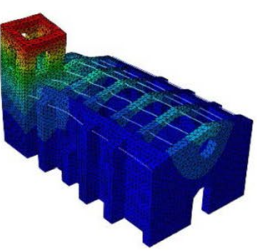

Mode 12 $\mathbf{T}=0.187 \mathrm{~s}$ PMR long. $=23.70 \%$ PMR trans. $=1.64 \%$

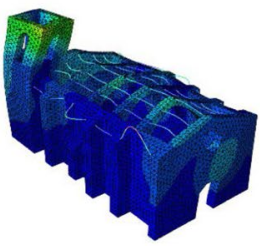

Mode 22

$$
\mathbf{T}=0.098 \mathrm{~s}
$$

PMR long. $=0.69 \%$

PMR trans. $=2.23 \%$

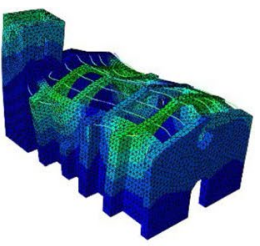

Mode 13 $\mathbf{T}=0.158 \mathrm{~s}$ PMR long. $=0.11 \%$ PMR trans. $=2.58 \%$

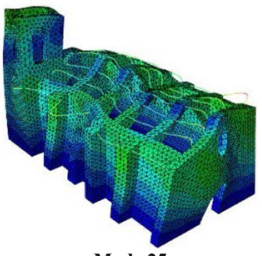

Mode 25

$$
\mathbf{T}=0.090 \mathrm{~s}
$$

PMR long. $=0.00 \%$ PMR trans. $=0.42 \%$

Fig. 11 Modal shapes of the 2016 roof configuration (timber roof) with the relative values of the periods (T) and the participating mass ratios in the longitudinal (PMR long.) and transversal (PMR trans.) directions 
Table 6 Comparison between the main vibration modes for the configurations with a concrete roof and a timber roof

\begin{tabular}{|c|c|c|c|c|c|c|c|c|}
\hline \multirow[t]{2}{*}{ Direction } & \multicolumn{3}{|c|}{ Concrete roof } & \multicolumn{3}{|c|}{ Timber roof } & \multicolumn{2}{|l|}{ Difference* } \\
\hline & Mode & Period (s) & $\begin{array}{l}\text { Participat- } \\
\text { ing mass } \\
\text { ratio }(\%)\end{array}$ & Mode & Period (s) & $\begin{array}{l}\text { Participat- } \\
\text { ing mass } \\
\text { ratio }(\%)\end{array}$ & Period (\%) & $\begin{array}{l}\text { Participating } \\
\text { mass ratio } \\
(\%)\end{array}$ \\
\hline Transversal & 1 & 0.208 & 59.26 & 9 & 0.257 & 40.49 & -20 & 18.77 \\
\hline \multirow{2}{*}{$\begin{array}{l}\text { Longitudi- } \\
\text { nal }\end{array}$} & 2 & 0.161 & 24.82 & 12 & 0.187 & 23.70 & -14 & 1.12 \\
\hline & 6 & 0.108 & 34.51 & 14 & 0.130 & 19.50 & -17 & 15.01 \\
\hline
\end{tabular}

*The differences are calculated considering the timber roof configuration as a reference

\subsubsection{Seismic analyses}

The different seismic responses of the two configurations were evaluated through nonlinear implicit dynamic analyses. The two accelerograms described in Sect. 3 were applied to both models. Each analysis lasted approximately $6 \mathrm{~h}$ on a computer with a Linux operating system, a 4-core Intel Core i7-6700 K CPU and 32 GB of RAM. The maximum size of the time step was set at $0.005 \mathrm{~s}$, but at some instances, the analyses required further reduction for convergence.

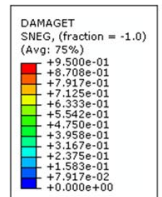

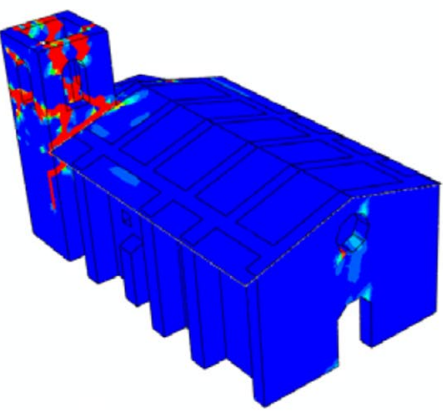

(a)

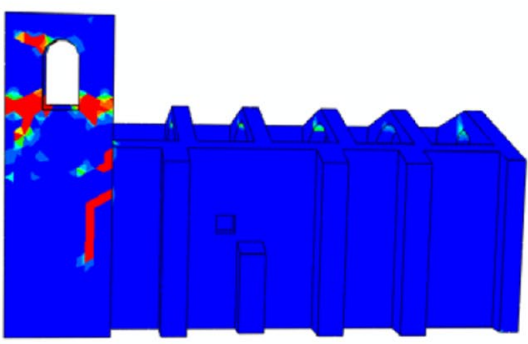

(c)

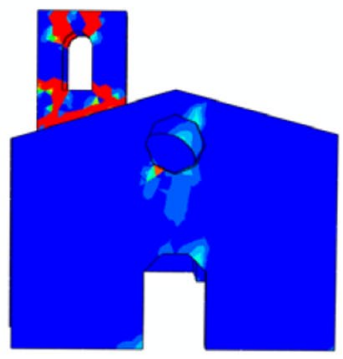

(b)

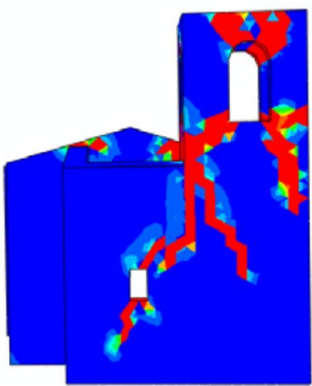

(d)

Fig. 12 Results of the seismic analyses, earthquake of September 27, 1997: a north-west view; b west view; c north view; d east view 
The results of the analyses are reported here in terms of contour maps of the tensile damage $d_{t}$. The numerical results reproduce the damage described in Sect. 2.2. Applying the September 1997 shock to the 1997 configuration, the observed damage to the triumphal arch (Fig. 12a), the façade (Fig. 12b), the bell tower (Fig. 12c), and the apse (Fig. 12d) was obtained, validating the assumptions of a full connection between the concrete roof and masonry elements (bell tower and underlying masonry structures). No damage in the buttresses and lateral walls emerged from the analysis. The damage in the buttresses (Fig. 4d) is probably due to reconstruction at different times, while disintegration of the external leaf occurred at the lateral walls (Fig. 4c). These types of damage were not observed in the analyses because local characteristics are difficult to include in a global model.

Figure 13 reports the damage contour map obtained by applying the 2016 shock to the 2016 model. More specifically, Fig. 13a shows the damage at the base of the longitudinal nave in the interior side of the south wall and damage in the arches at the connection with the timber beams of the roof. It also shows local damage in the façade at the intersection with the transversal walls of the nave, without showing any damage in the rest of the façade (Fig. 13b). Damage between the bell tower and the

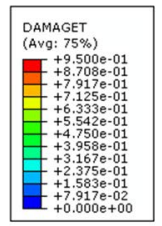

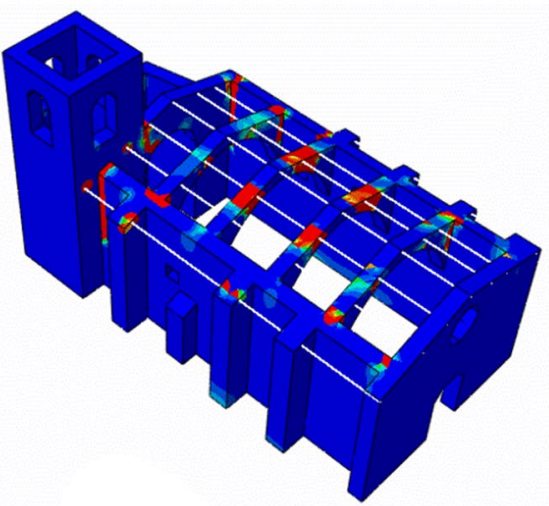

(a)

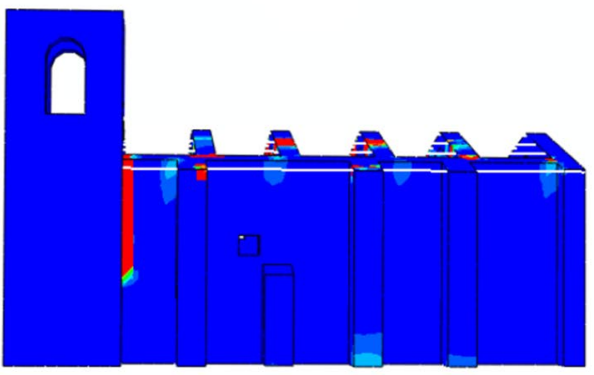

(c)

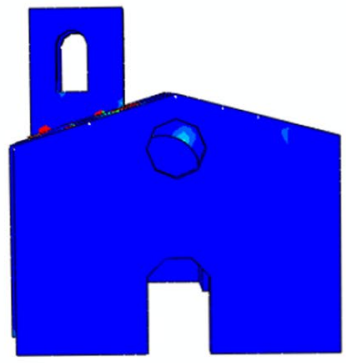

(b)

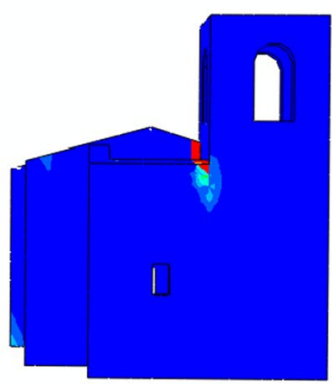

(d)

Fig. 13 Results of analyses for the 2016 configuration for the October 30, 2016, earthquake: a north-west view; b west view; c north view; $\mathbf{d}$ east view 
rest of the structure on the east and north sides (vertical crack) was also observed (Fig. 13c, d).

Once the model was validated by comparing the numerical results with the damage that occurred, two further analyses were performed to investigate the effect of the two intervention modalities, applying the 2016 earthquake to the 1997 configuration (Fig. 14) and the 1997 earthquake to the 2016 configuration (Fig. 15). From the comparison of Figs. 12 with 14 and of Figs. 13 with 15, the damage pattern appears independent from the specific characteristics of the seismic events. At this point, some considerations of the influence of the roof type can be expressed:

- The concrete roof resulted in a box-like behavior but caused a concentration of damage in the façade and in the bell tower (Fig. 12a, b).

- The timber roof produced local damage, concentrated on the arches and on the intersection between the transversal walls and the façade (Figs. 12a, 13a, 14a, 15a).

- Moreover, an independent structural response of the bell tower was observed in the 2016 configuration. In this case, the timber roof was not in a condition to tie together the structure of the church and of the bell tower, causing less damage in

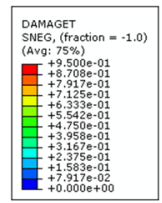

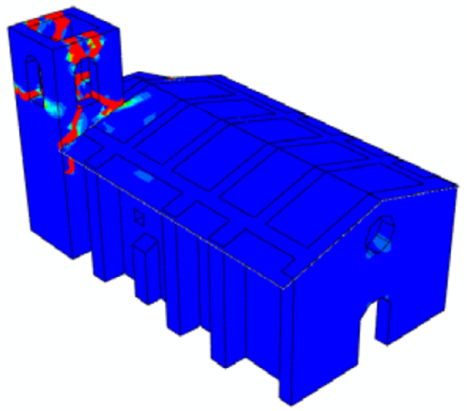

(a)

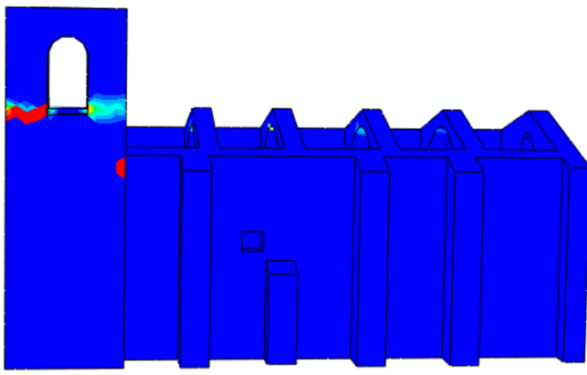

(c)

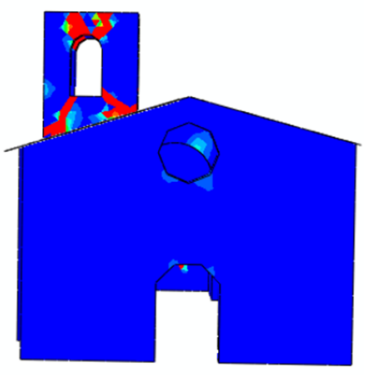

(b)

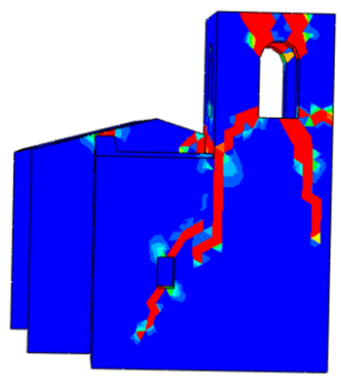

(d)

Fig. 14 Results of the seismic analyses for the 1997 configuration with the 2016 earthquake: a north-west view; b west view; c north view; $\mathbf{d}$ east view. Note the concrete roof was hidden to clearly show the damage that occurred in the various elements of the church 
the apse and bell tower but producing a pounding effect at their connection and between the lateral wall of the nave and the bell tower (Figs. 13c, 15c).

To further investigate the influence of the roof intervention on the structural behavior, the displacement of specific points of the church was plotted. Figure 16 shows a comparison of the displacement time history of four points in the two church configurations after application of the 1997 earthquake. This confirms how the change in the roof significantly modifies the response of the bell tower, with a significant reduction in the damage and in the displacements with the timber roof (Fig. 16a, b). Focusing on the nave, the timber roof does not constrain the lateral walls, which, for this reason, tend to bend horizontally more in the 2016 than in the 1997 configuration. The damage contour plot and the damage at the corners of the lateral walls confirm this trend $(15 \mathrm{a}, 15 \mathrm{c})$. Regardless, the residual displacement is limited due to the tie rods and the buttresses that constrain it (Fig. 16c). Regarding the façade, the concrete roof reduces the displacements in the gable (Fig. 16d) but increases the out-of-plane displacements at the center of the façade (Fig. 16e), as already shown by the modal shapes.

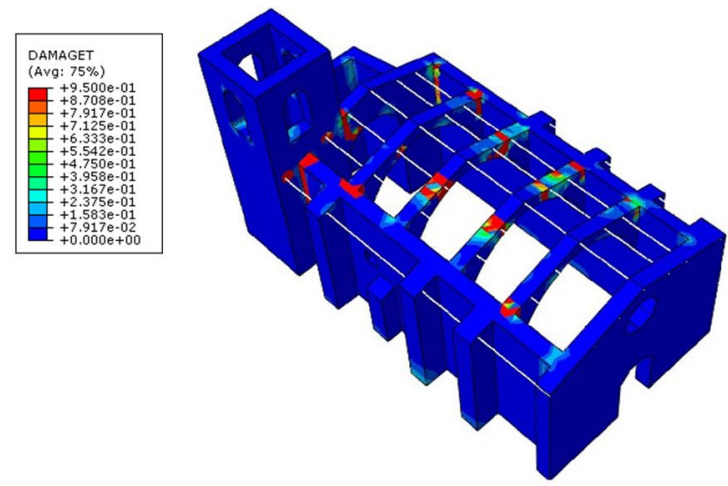

(a)

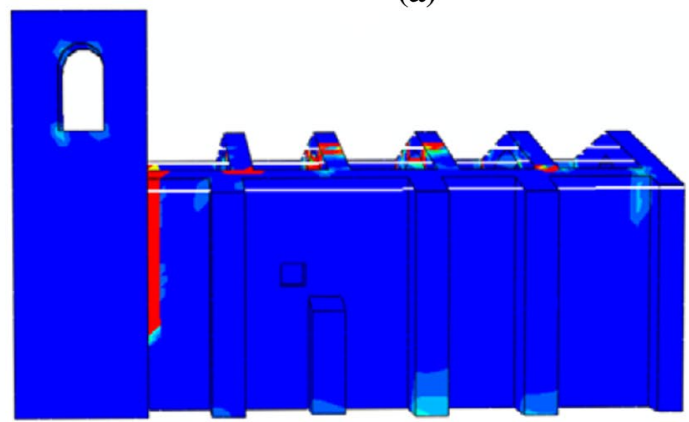

(c)

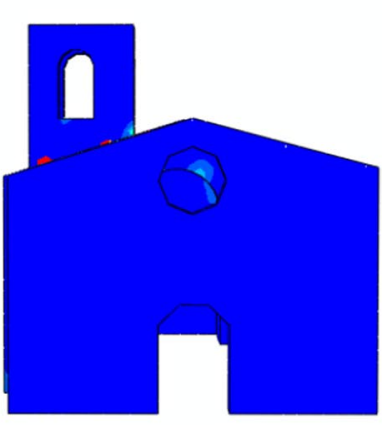

(b)

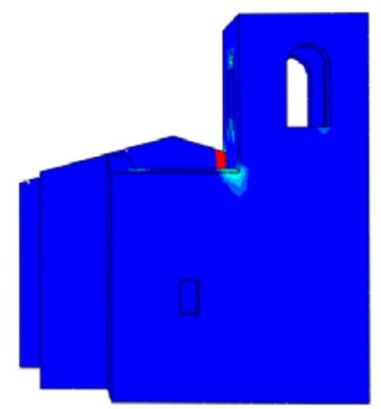

(d)

Fig. 15 Results of the seismic analyses for the 2016 configuration with the 1997 earthquake: a north-west view; $\mathbf{b}$ west view; $\mathbf{c}$ north view; $\mathbf{d}$ east view 


\section{$\mathrm{RC}$ roof configuration}

Point 1 longitudinal direction

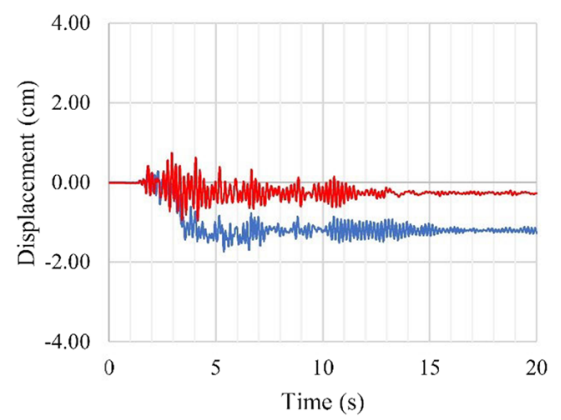

(a)

Point 2

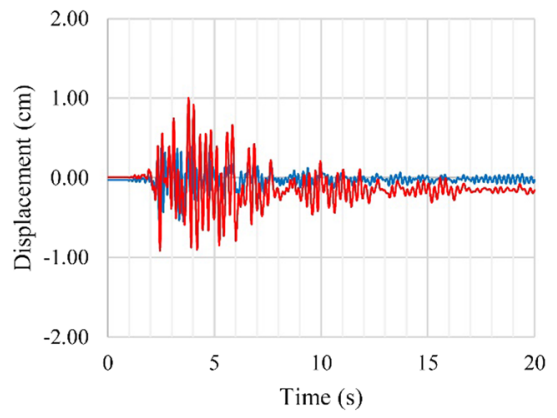

(c)

Point 4

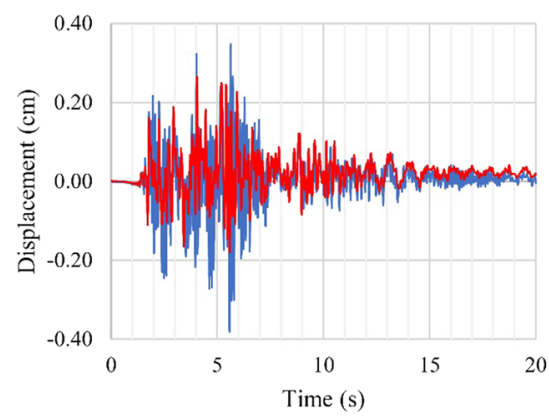

(e)

\section{Timber roof configuration}

Point 1 transversal direction

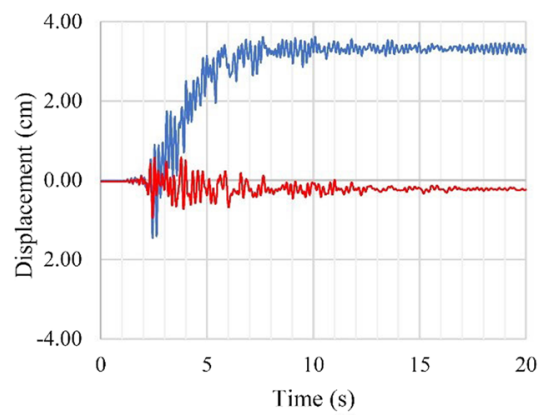

(b)

Point 3

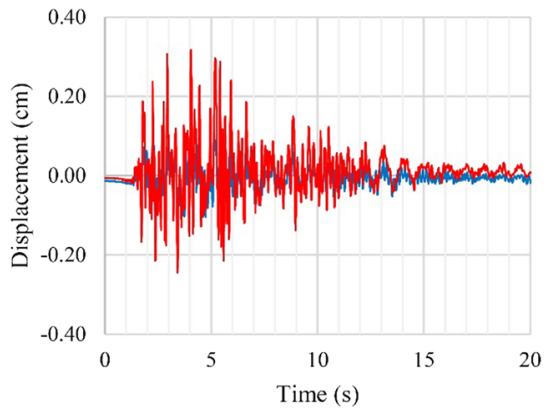

(d)

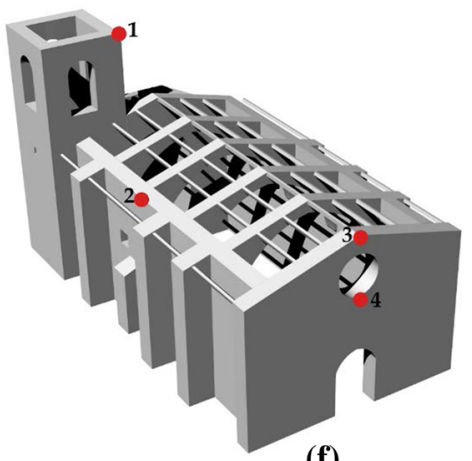

(f)

Fig. 16 Comparison of the displacement-time history of the two church configurations subjected to the 1997 earthquake. Locations of reference points can be seen in (f) 


\section{Analysis of the façade macroelement with the RBSM}

The mechanical behavior of multileaf masonry depends on the stone pattern of the external leaves, which implies an orthotropic response, and on the interlocking among the three leaves. This last aspect strongly affects the out-of-plane behavior of the masonry walls because the leaves are usually poorly connected, generating a higher vulnerability of the masonry walls for out-of-plane loadings. To simulate a more realistic behavior of the masonry, a simplified approach, implemented in an out-of-plane rigid body spring model (Casolo and Uva 2013), was used with the aim of evaluating the seismic response of the façade macroelement in the two configurations (Fig. 9).

Façade damage usually develops as cylindrical yield lines (hinges). For this reason, the use of an out-of-plane RBSM that follows the Kirchhoff-Love plate theory is justified. In this type of study, the membrane dynamic effects and the in-plane damage mechanisms are neglected. The façade is modeled with rigid quadrilateral plane elements, connected in pairs, through two elastic-plastic rotational springs: one for bending and one for twisting (Casolo 2000). In the definition of the spring response, the different bending behaviors in the horizontal and vertical directions are considered. On the one hand, the horizontal hinge behavior is a function of the normal stress state in the leaves (due to the curvature $\chi$ ) and their interlocking. In this case, the three leaves are assumed to fully collaborate until the residual cohesion value is reached in the infill core. Subsequently, the bending strength of the walls is computed as the sum of the bending strengths of the distinct leaves, increased by a fixed moment, that considers the degree of collaboration among them. This additional moment is evaluated assuming a shear stress on the infill-block interface equal to the residual cohesion of the infill. Once the masonry leaves are uncoupled, the vertical hinge response is a function of the shear stress state in the mortar interfaces (Casolo 2017), which considers the vertical compression due to self-weight. For the twisting springs, an average of the bending spring laws is considered, as validated in (Casolo and Milani 2013).

\subsection{The numerical model and the used material properties}

In the model, not only the façade but also the lateral walls up to the first buttresses were considered. Assuming a perfect connection between the lateral walls and the façade and

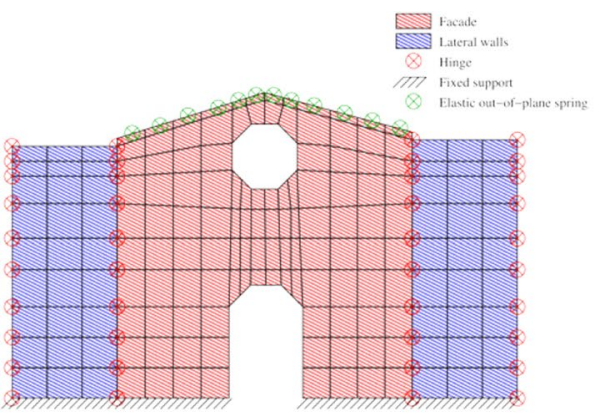

(a)

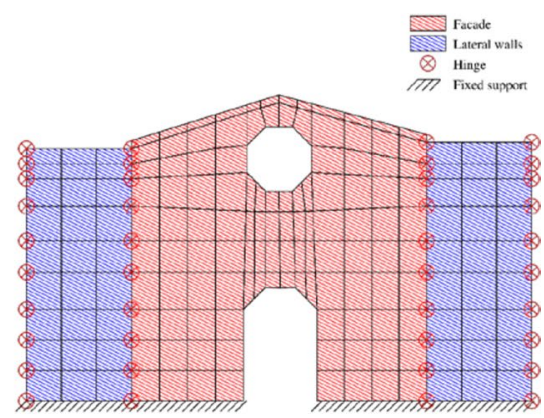

(b)

Fig. 17 The quadrilateral mesh considered in the RBSM and the assigned boundary conditions for the 1997 configuration (a) and the 2016 configuration (b). Note The lateral walls are plotted coplanar with the façade 

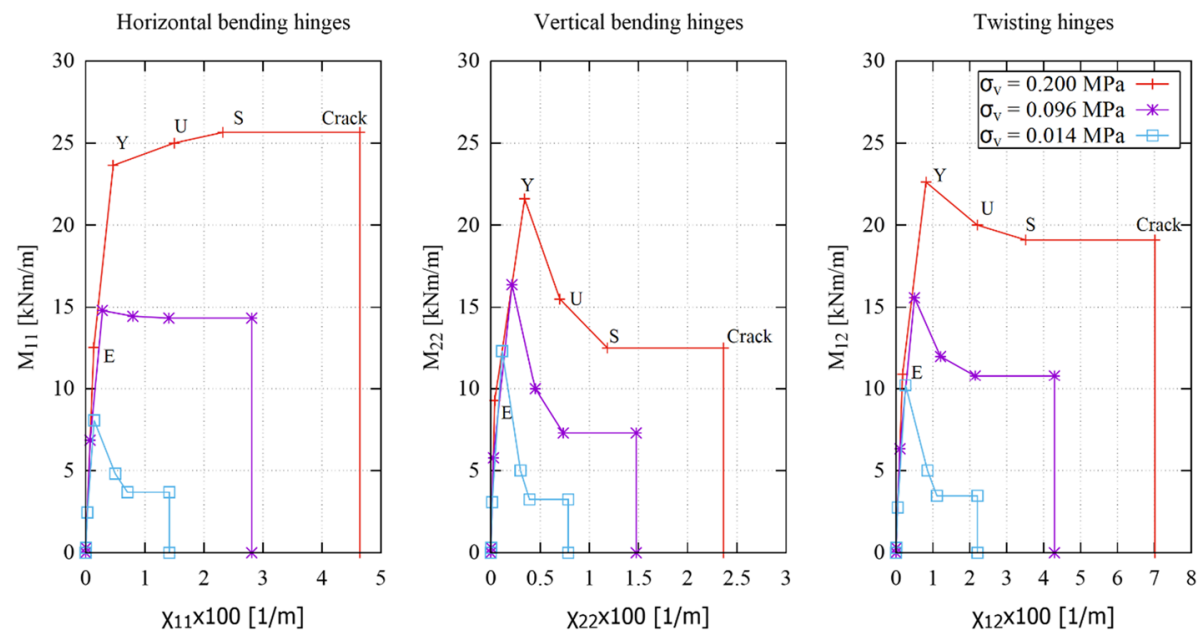

Fig. 18 Moment-curvature relationships of the bending and twisting hinges of the façade for different levels of vertical stress $\sigma_{\mathrm{v}}$ due to the wall self-weight. More specifically, the piecewise linear moment-curvature law is progressively defined from the point $E$ to the point $C r a c k$, which represents failure. The intermediate points are called $Y, U, S$

Table 7 Material properties assigned to the masonry leaves

\begin{tabular}{|c|c|c|c|}
\hline $\begin{array}{l}\text { External leaf material } \\
\text { Thickness }=20 \mathrm{~cm} \\
(E=1600 \mathrm{MPa})\end{array}$ & & $\begin{array}{l}\text { Inner core material } \\
\text { Thickness }=50 \div 43 \mathrm{~cm} \\
(E=800 \mathrm{MPa})\end{array}$ & \\
\hline Tensile behavior & & Tensile behavior & \\
\hline$\varepsilon(\times 1000)$ & $\sigma(\mathrm{MPa})$ & $\varepsilon(\times 1000)$ & $\sigma(\mathrm{MPa})$ \\
\hline 0.0000 & 0.0000 & 0.0000 & 0.0000 \\
\hline 0.0234 & 0.0375 & 0.0234 & 0.0188 \\
\hline 0.1875 & 0.1500 & 0.1875 & 0.0750 \\
\hline 0.3750 & 0.0037 & 0.3750 & 0.0019 \\
\hline Compressive behavior & & Compressive behavior & \\
\hline$\varepsilon(\times 1000)$ & $\sigma(\mathrm{MPa})$ & $\varepsilon(\times 1000)$ & $\sigma(\mathrm{MPa})$ \\
\hline 0.0000 & 0.0000 & 0.0000 & 0.0000 \\
\hline 1.0000 & 1.6000 & 0.8750 & 0.7000 \\
\hline 4.0000 & 3.0000 & 3.5000 & 0.8000 \\
\hline 8.0000 & 0.1600 & 7.0000 & 0.0700 \\
\hline $\begin{array}{l}\text { Shear behavior } \\
(\mathrm{G}=400 \mathrm{MPa})\end{array}$ & & $\begin{array}{l}\text { Shear behavior } \\
(\mathrm{G}=400 \mathrm{MPa})\end{array}$ & \\
\hline$\gamma(\times 1000)$ & $\tau(\mathrm{MPa})$ & $\gamma(\times 1000)$ & $\tau(\mathrm{MPa})$ \\
\hline 0.0000 & 0.0000 & 0.0000 & 0.0000 \\
\hline 0.0469 & 0.0188 & 0.0469 & 0.0188 \\
\hline 0.3750 & 0.0750 & 0.3750 & 0.0750 \\
\hline 0.7500 & 0.0019 & 0.7500 & 0.0019 \\
\hline
\end{tabular}

that the lateral walls were infinitely stiff for in-plane loads, the lateral walls constrain the out-of-plane displacements in the corners of the façade. Furthermore, the connection allows us to consider the bending effects on the façade from a seismic action on the 
transversal walls, and vice versa. Figure 17 shows the mesh used for the analyses and the boundary conditions. To reproduce the 1997 and 2016 roof configurations, two different models were considered. In the 1997 configuration, the presence of the concrete roof was modeled by constraining the displacement at the top of the façade with elastic out-of-plane springs (Fig. 17a). The spring stiffness was assumed to be $3 \times 10^{7} \mathrm{~N} / \mathrm{m}$, reproducing with the local model the deformed shape of mode 8 of the $3 \mathrm{D}$ model, which mainly involves the façade (Fig. 10). By contrast, in the 2016 configuration, the transversal displacements at the top of the façade were left unrestrained, considering negligible the constraint of the timber roof (Fig. 17b).

The moment-curvature relationships of the bending and twisting rotational springs (Fig. 18) were obtained by assigning the material properties (Table 7) to the layers of the three-leaf masonry. The inner core of the wall was considered $50 \mathrm{~cm}$ thick for the façade and $43 \mathrm{~cm}$ thick for the lateral walls, while the external leaves were kept constant $(20 \mathrm{~cm})$.

\subsection{Numerical results}

In the following sections, the analyses performed with the RBSM on the façade are reported. Initially, the results of the frequency analyses are proposed for validating the boundary conditions imposed on the local model. For this purpose, the modal shapes obtained from the local model are compared with those from the global model discussed in Sect. 4.2.1. Section 5.2.2 shows the results of the nonlinear implicit dynamic analyses performed for the two seismic events with the two configurations.

\subsubsection{Frequency analysis}

Figure 19 shows the displacement maps of the first three vibration modes of the façade macroelements. A significant change in the modal shapes and a reduction in the periods from the 1997 to the 2016 configurations appear (see Table 8). In particular, the first modal shape of the 1997 configuration (Fig. 19a) is a vertical bending deformed shape with the maximum displacement at the center of the façade. The modal shape is similar to mode 8 of the 3D model (Fig. 10), and the period differs by no more than $10 \%$, validating the boundary conditions assigned in the local model. In the 2016 configuration, the first modal shape (Fig. 19d) is still a vertical bending deformed shape, but with the maximum displacement at the top, as observed for mode 14 of the global model (Fig. 11). For the 1997 configuration, the second modal shape is a horizontal bending deformed shape with an inflection point in the axis of the façade (Fig. 19b). The third modal shape is another vertical bending deformed shape, with a null displacement in the center of the façade (Fig. 19c). Instead, for the 2016 configuration, the second modal shape is a vertical bending deformed shape, with a null displacement at the rose window height (Fig. 19e). The third modal shape is a horizontal bending deformed shape like the second one of the 1997 configuration (Fig. 19f). 


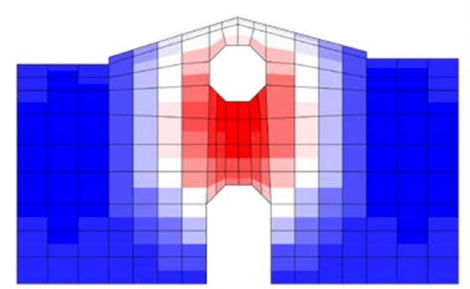

(a)

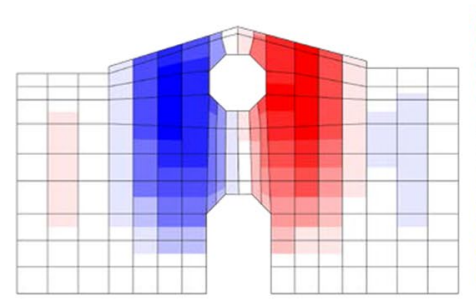

(b)

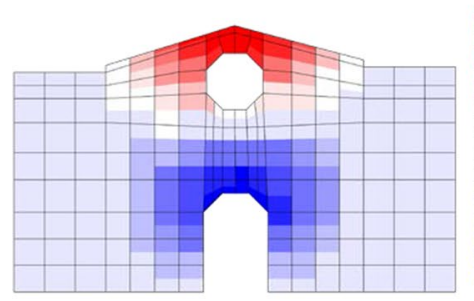

(c)

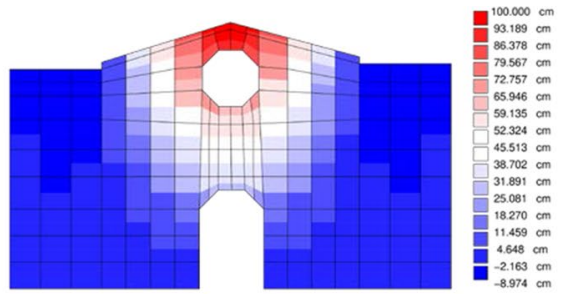

(d)

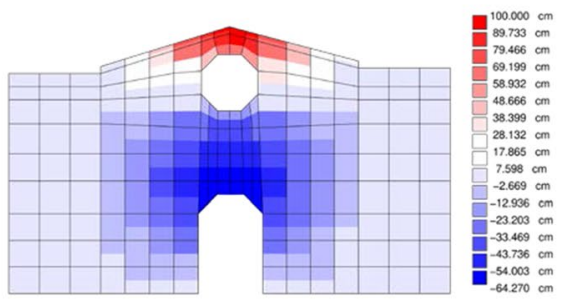

(e)

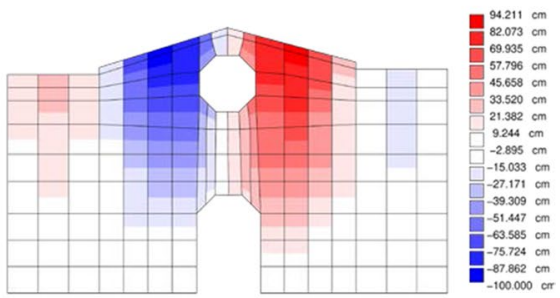

(f)

Fig. 19 Displacement contour maps of the modal shapes of the RBSM façade for the 1997 configuration (a-c) and the 2016 configuration (d-f)

Table 8 Comparison of the periods of the first three vibration modes for the two configurations (1997 and 2016)

\begin{tabular}{lll}
\hline Mode & 1997 Configuration Period (s) & 2016 Configuration Period (s) \\
\hline 1 & 0.083 & 0.132 \\
2 & 0.044 & 0.056 \\
3 & 0.041 & 0.049 \\
\hline
\end{tabular}

\subsubsection{Seismic analyses}

Considering both configurations and both seismic events, four analyses were performed. The response of the façade was evaluated by plotting the maximum absolute values of the curvature $\chi$ reached in the rotational springs compared with the points $(\mathrm{Y}, \mathrm{U}, \mathrm{S}$, Crack) of the piecewise M- $\chi$ laws of Fig. 18. The bending hinge curvature was plotted as a colored straight line over the edge of the connection, while the twisting hinge curvature was plotted with a colored cross at the connection point (Fig. 20).

Observing the damage patterns, the failure mechanism was modified by the constraint at the top of the façade. The damage was concentrated around the rose window and in the center of the façade in the 1997 configuration (Fig. 20a-c). In the configuration with the timber roof, the damage focuses on the rose window but with mainly vertical hinges 


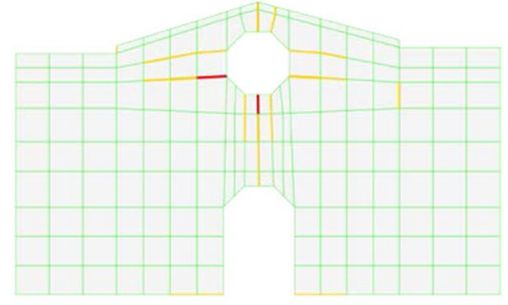

(a)

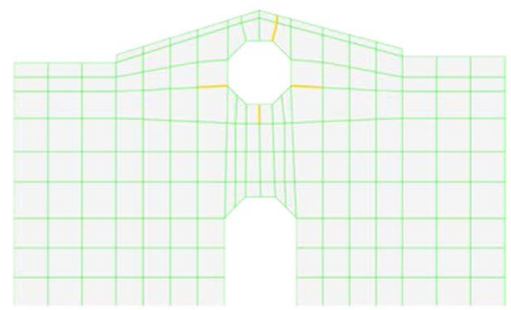

(c)

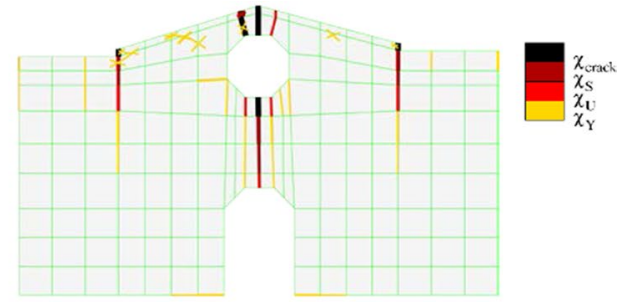

(b)

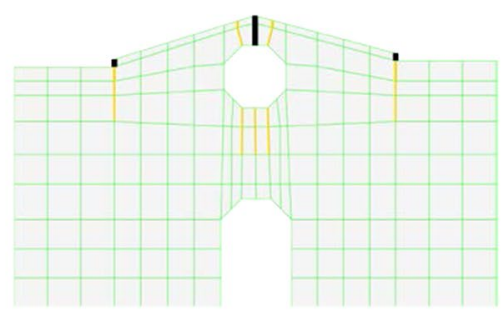

(d)

Fig. 20 Damage patterns obtained with the RBSM for the 1997 event in the 1997 configuration (a) and in the 2016 one (b); and for the 2016 earthquake in the 1997 configuration (c) and the 2016 one (d). The damage is obtained by comparing the maximum curvature, reached in the rotational springs, with the curvature at the points $\mathrm{Y}, \mathrm{U}, \mathrm{S}$, and $\operatorname{Crack}\left(\chi_{\mathrm{y}}, \chi_{\mathrm{u}}, \chi_{\mathrm{s}}, \chi_{\text {crack }}\right)$

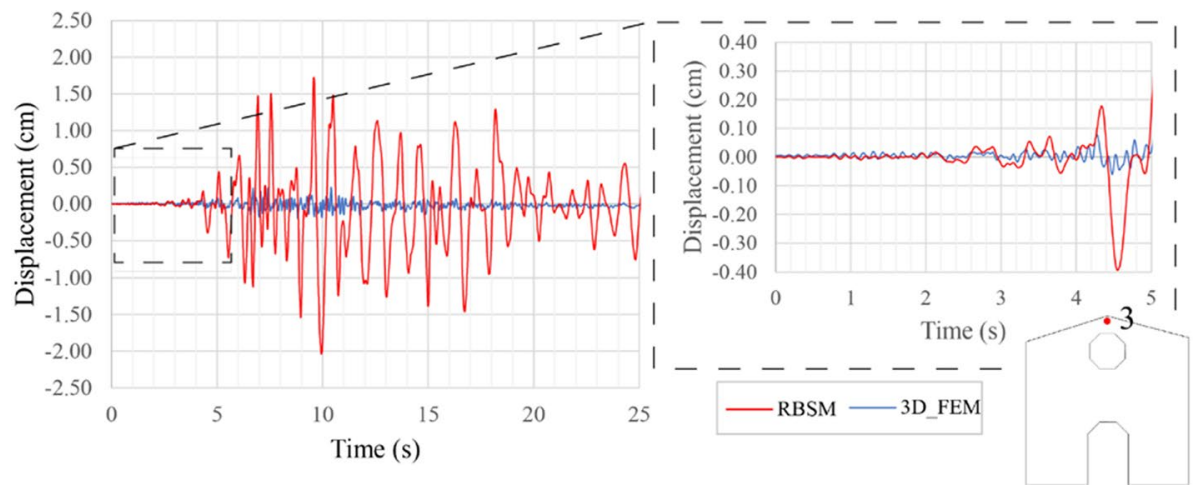

Fig. 21 Comparison of the time history responses in terms of the displacement of point P3 (the same point of Fig. 16) at the façade vertex, obtained with the 3D FEM and the RBSM for the 2016 event and the 2016 configuration. On the right, an enlarged view of the first $5 \mathrm{~s}$ of the displacement history

that cross the window from the top to the center of the façade (Fig. 20b, d). In these last cases, some damage was also visible at the intersection between the façade and the lateral walls. Moreover, for the 2016 shock, both configurations were almost undamaged, as observed in the 2016 configuration after the 2016 earthquake.

Figure 21 shows the time history response in terms of the displacement of point $\mathrm{P}$ of the façade in the 2016 configuration for the 2016 event. The comparison of these displacements with those obtained from the global 3D finite element model shows that the 
RBSM values are higher but more similar to those obtained in other studies on the outof-plane response of masonry façades (Costa et al. 2012, 2013; Bertolesi et al. 2018a). However, zooming in on the first $5 \mathrm{~s}$ of the graph, this difference is almost negligible; therefore, the difference between the two models is mainly due to the different postelastic behaviors. In fact, the RBSM considers the three masonry leaves almost completely uncoupled after an initial monolithic response due to the poor mechanical properties of the inner core. This poor interlocking among stones and the inner core significantly reduced the postelastic stiffness, different from the isotropic and homogeneous FEMs used for the global analyses.

\section{Conclusions}

This study investigated the structural response of the church of San Salvatore in Acquapagana, which was struck by two important seismic events: the 1997 Umbria-Marche and the 2016 Central Italy earthquakes. Between these two episodes, some repairing and rebuilding works were performed, and the concrete roof was replaced with a light timber roof. Particular emphasis was placed on the influence of the roof typology on the structural response, analyzed with two approaches: at the building scale, with a finite element model, and at the façade macroelement scale, with an out-of-plane rigid body spring model.

The modal analyses, performed with the finite element model, showed how the concrete roof provides a more effective box-like structural behavior than does the timber roof. This effect is guaranteed not only by the constitutive characteristics of the roof but also by the connection with the underlying structure. This type of roof reduces the displacements of the gable, increasing, at the same time, the out-of-plane displacements in the center of the façade. Dynamic analyses indicated that damage was concentrated in the belfry, the bell tower walls, the triumphal arch, and the façade. The area of the gable in contact with the concrete roof and the center of the façade were the most damaged parts. The results agree with the observed damage.

In the timber roof configuration, the lateral walls tend to inflect more, being less constrained than in the former case, and move in parallel, being connected by the stiff arches and tie-rods. In this configuration, damage concentrates at the interface between the bell tower and the church and between the bell tower and the apse. The façade seems almost undamaged for both seismic events, except for minor damage at the intersection with the lateral walls of the nave. The tendency of the lateral walls to deflect explains the slight damage visible in the façade at the intersection with the transversal structures and at the base. Finally, the arches are damaged in correspondence with the roof beams.

After a preliminary validation comparing the results of the modal analyses, the rigid body spring model was used to study the structural response of the façade macroelement. The dynamic analyses demonstrated that the presence of the concrete roof anchored to the façade caused damage that was concentrated at the center of the façade. By contrast, in the case of the timber roof, this model showed the formation of a vertical hinge in the center of the façade, where no severe damage was reported in the global model. This result was possible thanks to the particularity of the RBSM, which allowed us to consider the orthotropic behavior of the masonry and its leaf structure. These damage results satisfactorily match the actual damage that occurred after the 2016 earthquake, concentrated in the center of the façade and at the intersection between the façade and the lateral walls. 
Acknowledgements The financial support provided to the first and third authors by the RELUIS-DPC Program is gratefully acknowledged.

Funding Open access funding provided by Politecnico di Milano within the CRUI-CARE Agreement.

Open Access This article is licensed under a Creative Commons Attribution 4.0 International License, which permits use, sharing, adaptation, distribution and reproduction in any medium or format, as long as you give appropriate credit to the original author(s) and the source, provide a link to the Creative Commons licence, and indicate if changes were made. The images or other third party material in this article are included in the article's Creative Commons licence, unless indicated otherwise in a credit line to the material. If material is not included in the article's Creative Commons licence and your intended use is not permitted by statutory regulation or exceeds the permitted use, you will need to obtain permission directly from the copyright holder. To view a copy of this licence, visit http://creativecommons.org/licenses/by/4.0/.

\section{References}

Abaqus (2016) Theory manual, version 2016

Acito M, Bocciarelli M, Chesi C, Milani G (2014) Collapse of the clock tower in Finale Emilia after the May 2012 Emilia Romagna earthquake sequence: numerical insight. Eng Struct 72:70-91

Arias A (1970) A measure of earthquake intensity. In: Hansen RJ (ed) Seismic Design for Nuclear Power Plants. MIT Press, Cambridge, pp 438-483

Bejarano-Urrego L, Verstrynge E, Giardina G, Van Balen K (2018) Crack growth in masonry: numerical analysis and sensitivity study for discrete and smeared crack modelling. Eng Struct 165:471-485

Bertolesi E, Milani G, Casolo S (2018a) Homogenization towards a mechanistic Rigid Body and Spring Model (HRBSM) for the non-linear dynamic analysis of 3D masonry structures. Meccanica 53(7):1819-1855

Bertolesi E, Milani G, Fagone M, Rotunno T, Grande E (2018b) Micro-mechanical FE numerical model for masonry curved pillars reinforced with FRP strips subjected to single lap shear tests. Compos Struct 201:916-931

Binda L, Saisi A (2005) Research on historic structures in seismic areas in Italy. Prog Struct Mat Eng 7:71-85

Binda L, Chesi C, Parisi MA (2010) Seismic damage to churches: observations from L'Aquila, Italy, earthquake and considerations on a case study. Adv Mater Res 133-134:641-646

Borri A, Corradi M, Castori G, Sisti R, De Maria A (2018) Analysis of the collapse mechanisms of medieval churches struck by the 2016 Umbrian earthquake. Int J Arch Herit 13(2):215-228

Brandonisio G, Lucibello G, Mele E, De Luca A (2013) Damage and performance evaluation of masonry churches in the 2009 L'Aquila earthquake. Eng Fail Anal 34:693-714

Carbonari S, Catanzaro A, D'Agostino V, Dall'Asta V, Dezi L, Gara F, Leoni G, Morici M, Prota A (2017) Prime analisi e considerazioni circa di danni rilevati al patrimonio culturale delle marche a valle del terremoto del Centro Italia (2016). In: Proceedings of the Associazione Nazionale Italiana Di Ingegneria Sismica 2017, XVII Convegno L'Ingegneria sismica in Italia, Pistoia, Italy, 17-21 September 2017 (in Italian)

Casolo S (2000) Modelling the out-of-plane seismic behaviour of masonry walls by rigid elements. Earthq Eng Struct Dyn 29(12):1797-1813

Casolo S (2017) A numerical study on the cumulative out-of-plane damage to church masonry façades due to a sequence of strong ground motions. Earthq Eng Struct Dyn 46:2717-2737

Casolo S, Milani G (2013) Simplified out-of-plane modelling of three-leaf masonry walls accounting for the material texture. Constr Build Mater 40:330-351

Casolo S, Uva G (2013) Nonlinear analysis of out-of-plane masonry façades: full dynamic versus pushover methods by rigid body and spring model. Earthq Eng Struct Dyn 42(4):499-521

Casolo S, Diana V, Uva G (2017) Influence of soil deformability on the seismic response of a masonry tower. Bull Earthq Eng 15(5):1991-2014

CEN (2005) Eurocode 8: Design of structures for earthquake resistance. Part 1: General rules, seismic actions and rules for buildings, Brussels

Cescatti E, Taffarel S, Leggio A, Da Porto F, Modena C (2017) Macroscale damage assessment of URM churches after the 2016 earthquake sequence in Centre of Italy. In: Proceedings of the Associazione Nazionale Italiana Di Ingegneria Sismica 2017, XVII Convegno L'Ingegneria sismica in Italia, Pistoia, Italy, 17-21 September 2017 
CMIT (2009) Circolare 26 Febbraio 2009, n. 617 C.S.LL.PP. Istruzioni per l'applicazione dell' «Aggiornamento delle " Norme tecniche delle costruzioni'" 》 di cui al decreto ministeriale 14 gennaio 2008 (GU Serie Generale n. 47 del 26-02-2009 - Suppl. Ordinario n. 27) (in Italian)

CMIT (2019) Circolare 21 Gennaio 2019, n. 7 C.S.LL. PP. Istruzioni per l'applicazione dell' «Aggiornamento delle " Norme tecniche delle costruzioni" $\gg$ di cui al decreto ministeriale 17 gennaio 2018. (GU Serie Generale n. 35 del 11-02-2019 - Suppl. Ordinario n. 5) (in Italian)

Costa AA, Arêde A, Costa A, Oliveira CS (2012) Out-of-plane behaviour of existing stone masonry buildings: experimental evaluation. Bull Earthq Eng 10(1):93-111

Costa AA, Arêde A, Costa AC, Penna A, Costa A (2013) Out-of-plane behaviour of a full scale stone masonry façade. Part 2: shaking table tests. Earthq Eng Struct Dyn 42:2097-2111

Da Porto F, Silva B, Costa C, Modena C (2012) Macro-scale analysis of damage to churches after earthquake in Abruzzo (Italy) on April 6, 2009. J Earthq Eng 16:739-758

D'Ayala D, Benzoni G (2012) Historic and traditional structures during the 2010 chile earthquake: observations, codes, and conservation strategies. Earthq Spectra 28(S1):S425-S451

DCPCM-DPC MIBAC (2006) Form of damage for churches. Form A. http://www.beniculturali.it/mibac /multimedia/MiBAC/documents/1338454237471_allegato4.pdf Accessed 1 September 2018 (in italian)

De Borst R (1997) Some recent developments in computational modelling of concrete fracture. Int $\mathbf{J}$ Fract 86:5-36

De Matteis G, Zizi M, Corlito V (2017) Analisi preliminare degli effetti del terremoto del Centro Italia del 2016 sulle chiese a una navata. In: Proceedings of the Associazione Nazionale Italiana Di Ingegneria Sismica 2017, XVII Convegno L'Ingegneria sismica in Italia, Pistoia, Italy, 17-21 September 2017 (in Italian)

Doglioni F, Mazzotti P (2007) Codice di pratica per gli interventi di miglioramento sismico nel restauro del patrimonio architettonico. Integrazioni alla luce delle esperienze della regione marche. Ed. Regione Marche, Italy (in Italian)

Doglioni F, Moretti A, Petrini V (1994) Le Chiese e il Terremoto. LINT Press, Trieste, Italy (in Italian)

Gruppo di Lavoro INGV sul terremoto in centro Italia (2016) Rapporto di sintesi sul Terremoto in centro Italia Mw 6.5 del 30 ottobre 2016. https://ingvterremoti.files.wordpress.com/2016/11/ita2016111 0_rapporto_centroitalia_def.pdf. Accessed 17 July 2018 (in Italian)

Housner G (1970) Earthquake engineering, chap: strong ground motion. Prentice-Hall, New York, pp 75-91

ICOMOS (2019). Charters adopted by the General Assembly of ICOMOS. https://www.icomos.org/en/ resources/charters-and-texts. Accessed 30 April 2019

Indirli M, Marghella G, Marzo A (2012) Damage and collapse mechanisms in churches during the Pianura Padana Emiliana earthquake. EAI Energia Ambiente e Innovazione 4-5:69-94

INGV (2015). DBMI 15. Catalogo Parametrico dei Terremoti Italiani 2015. https://emidius.mi.ingv.it/ CPTI15-DBMI15/. Accessed 16 March 2019

Lagomarsino, S (1998) Seismic damage survey of the churches in Umbria In Proceedings of the Works on Seismic Performance of Monuments, Lisbon, Portugal, 167-176

Lagomarsino S (2012) Damage assessment of churches after L'Aquila earthquake (2009). Bull Earthq Eng 10:73-92

Lagomarsino S, Podestà S (2004a) Seismic vulnerability of ancient churches: part 1. Damage assessment and emergency planning. Earthq Spectra 20(2):377-394

Lagomarsino S, Podestà S (2004b) Seismic vulnerability of ancient churches: part 2. Statistical analysis of surveyed data and methods for risk analysis. Earthq Spectra 20(2):395-412

Lee J, Fenves GL (1998) A plastic-damage model for earthquake analysis of dams. Earthq Eng Struct Dyn 27:937-956

Lourenço PB (2002) Computations on historic masonry structures. Prog Struct Mat Eng 4:301-319

Lubliner J, Oliver J, Oller S, Onate E (1989) A plastic-damage model for concrete. Int J Solids Struct 25(3):299-326

Luzi L, Pacor F, Puglia R (2019) Italian Accelerometric Archive v3.0. Istituto Nazionale di Geofisica e Vulcanologia, Dipartimento della Protezione Civile Nazionale. https://doi.org/10.13127/itaca.3.0

Marotta A, Sorrentino L, Liberatore D, Ingham JM (2017) Vulnerability assessment of unreinforced masonry churches following the 2010-2011 Canterbury earthquake sequence. J Earthq Eng 21(6):912-934

Modena C, Binda L (2009) Monumental historical buildings. Protection of the cultural heritage in the post-earthquake emergency. Progettazione Sismica 3:107-115

NTC (2018) Decreto Ministeriale 17 gennaio 2018 - "Norme tecniche per le costruzioni". Gazzetta Ufficiale n. 42, Suppl. Ordinario 20 February 2018 (in Italian) 
OPCM (2006) Pericolosità sismica del territorio nazionale. OPCM 3519 del 28 aprile 2006, All. 1b. http://zonesismiche.mi.ingv.it/. Accessed 2 April 2019

Penna A, Calderini C, Sorrentino L, Carocci C, Cescatti E, Sisti R, Borri A, Modena C, Prota A (2019) Damage to churches in the 2016 Central Italy earthquakes. Bull Earthq Eng 10:5763-5790

Petrini V, Casolo S, Doglioni F (1999) Model for vulnerability analysis of monuments and strengthening criteria. In: Proceedings of the XI European conference on earthquake engineering pp 179-198

Sarhosis V, Milani G, Formisano A, Fabbrocino F (2018) Evaluation of different approaches for the estimation of the seismic vulnerability of masonry towers. Bull Earthq Eng 16(3):1511-1545

Sferrazza Papa G, Silva B (2018) Assessment of Post-Earthquake Damage: St. Salvatore Church in Acquapagana, Central Italy. Buildings 8:45

Shake Map INGV (2019) Shake Map Archive. http://shakemap.rm.ingv.it/shake/index.html. Accessed 2 April 2019

Sorrentino L, Bucciarelli F, Decanini L D (2004) San Salvatore in Acquapagana: interpretazione sismica delle fasi costruttive. In: Proceedings of the Associazione Nazionale Italiana Di Ingegneria Sismica 2004, XI Convegno L'Ingegneria sismica in Italia, Genova, Italy, 25-29 Gennaio 2004 (in Italian)

Sorrentino L, Liberatore L, Decanini LD, Liberatore D (2014) The performance of churches in the 2012 Emilia earthquakes. Bull Earthq Eng 12:2299-2331

Sorrentino L, Doria M, Tassi V, Liotta MA (2019) Performance of a Far-Field Historical Church during the 2016-2017 Central Italy Earthquakes. J Perform Construct Facilit 33(2):1-15

Tobriner S, Comerio M, Green M (1997) Reconnaissance Report on the Umbria-Marche, Italy, Earthquakes of 1997, EERI Special Earthquake Report, December 1997, 1-12 https://www.eeri.org/lfe/pdf/Italy _Umbria_Marche_Insert_Dec97.pdf. Accessed 20 February 2019

UNI 11035-1:2010 (2010) Legno strutturale - Classificazione a vista dei legnami secondo la resistenza meccanica, UNI, Ente Italiano di Unificazione, Milano, Italy (in Italian)

Valente M, Milani G (2016) Non-linear dynamic and static analyses on eight historical masonry towers in the North-East of Italy. Eng Struct 114:241-270

Valente M, Milani G (2018a) Damage survey, simplified assessment, and advanced seismic analyses of two masonry churches after the 2012 Emilia earthquake. Int J Arch Herit 13(6):901-924

Valente M, Milani G (2018b) Damage assessment and partial failure mechanisms activation of historical masonry churches under seismic actions: three case studies in Mantua. Eng Fail Anal 92:495-519

Valente M, Milani G (2018c) Seismic response and damage patterns of masonry churches: seven case studies in Ferrara, Italy. Eng Struct 177:809-835

Valente M, Barbieri G, Biolzi L (2017) Damage assessment of three medieval churches after the 2012 Emilia earthquake. Bull Earthq Eng 15:2939-2980

Van Der Pluijm R (1993) Shear Behaviour of bed joints. In: Proceedings of 6th North American masonry conference, Philadelphia, pp 125-136

Publisher's Note Springer Nature remains neutral with regard to jurisdictional claims in published maps and institutional affiliations. 